\title{
The Potential of Variable Renewable Energy Sources in Mex- ico: A temporally-Evaluated and Geospatially-Constrained Techno-Economical Assessment
}

\author{
Edgar Ubaldo Peña Sanchez, ${ }^{*}$ a Severin David Ryberg, ${ }^{a}$ Heidi Ursula Heinrichs, ${ }^{a}$ Detlef Stolten, a,b and Martin Ro-

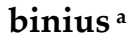

* Correspondence: author: e.pena.sanchez@fz-juelich.de

anstitute of Energy and Climate Research - Techno-economic Systems Analysis (IEK-3), Forschungszentrum Juelich $\mathrm{GmbH}$, 52425 Juelich, Germany

bRWTH Aachen University, Chair for Fuel Cells, Faculty of Mechanical Engineering, Kackertstraße 9, D-52072

Aachen, Germany

\begin{abstract}
Due to the increasing global importance of decarbonizing human activities, especially the production of electricity, the optimal deployment of renewable energy technologies will play a crucial role in future energy systems. To accomplish this, particular attention must be accorded to the geospatial and temporal distribution of variable renewable energy sources (VRES) such as wind and solar radiation in order to match electricity supply and demand. This study presents a techno-economical assessment of four energy technologies in the hypothetical context of Mexico in 2050, namely: onshore and offshore wind turbines, and open-field and rooftop photovoltaics. A land eligibility analysis incorporating physical, environmental, and socio-political eligibility constraints and individual turbine and photovoltaic park simulations, drawing on 39 years of climate data, is performed for individual sites across the country in an effort to determine the installable potential and the associated levelized costs of electricity. The results reveal that up to $54 \mathrm{PWh}$ of renewable electricity can be produced as a cost of less than $70 \mathrm{EUR} / \mathrm{MWh}$. Around $91 \%(49 \mathrm{PWh})$ of this would originate from $23 \mathrm{TW}$ of open-field photovoltaic parks that could occupy up to $578,000 \mathrm{~km}^{2}$ of eligible land across the country. The remaining $9 \%(4.8 \mathrm{PWh})$ could be produced by $1.9 \mathrm{TW}$ of onshore wind installations allocated to approximately $68,500 \mathrm{~km}^{2}$ of eligible land that is almost fully adjacent to three mountainous zones. The combination of rooftop photovoltaic and offshore wind turbines account for a very small share of less than $0.03 \%$ of the overall techno-economical potential.
\end{abstract}

Keywords: Renewable energy; land eligibility analysis; onshore wind; open-field photovoltaics; Mexico; renewable potential; technical potential

\section{Introduction}

The last decade has seen a significant increase in the contribution of renewable energy technologies to the reduction of anthropogenic $\mathrm{CO}_{2}$ emissions. Currently, renewables account for around $34 \%$ of global installed power capacity [1] and investments in them have grown steadily by at least $10 \%$ per year over the last decade [2], spurred by cost reductions and technological improvements [3]. Moreover, international commitments in the form of environmental policies and market integration mechanisms, such as those outlined in the 2015 Paris Climate Agreement [4], underpin the trend towards increasing renewable power generation. Hence, in order to aid policy initiatives and the other decisionmaking processes necessary for an effective energy transition, the generation potential of 
renewable energy technologies must be assessed with consideration given to their intrinsic geospatial and temporal heterogeneity for optimizing their use.

\subsection{Mexico's profile}

Mexico is currently an upper-middle-income country [5] with the world's fifteenth largest economy [6] and tenth largest population [7]. Its economy is closely linked to that of the rest of the world as a member of the United Nations, the World Trade Organization, the G8+5, the G20, and as a signatory to the Paris agreement, among other connections. In terms of energy, Mexico has traditionally been a crude oil exporter with a fossil fuel-intensive economy, notwithstanding a continuous 15-years decline in fossil fuel production that has been offset by increasing refined oil products and natural gas imports for fueling the country's transportation and power sectors [8]. In 2015, Mexico was responsible for the emission of $490 \mathrm{MtCO}_{2} \mathrm{eq}$ annually [9], making it the eleventh most polluting country worldwide and surpassing some fully industrialized economies, such as those of France and the United Kingdom [10]. In 2017, the power sector satisfied 330 TWh of electricity demand, of which only $15 \%$ originated from renewable sources [11], making it the second most polluting sector after transportation [9]. Moreover, over the last 13 years, Mexico's electricity consumption has steadily grown by $3 \%$ per year on average and is "directly" linked to the growth of gross domestic production [11].

In the coming years, Mexico not only has increasing green commitments to implement but also remaining energy challenges that should not be met at the expense of damaging the environment. For instance, it must provide reliable electricity access to an estimated 3.5 million people in remote areas [12] while at the same time reducing its total greenhouse gas emissions by $22 \%$ before 2030 [9]. Moreover, by 2050, Mexico's population is expected to reach over 155 million (nearly $25 \%$ more people than in 2020) [13] and its economy could become the world's sixth largest [14]. Thus, Mexico's energy needs will be even larger and more complex than those of today. Therefore, the development of its energy sector requires the integration of renewable energy sources. Fortunately, apart from traditional renewable sources such as hydropower, geothermal, and bioenergy, Mexico enjoys abundant sunshine across the country and regional strong winds that must be techno-economically assessed in order to optimize their use.

\subsection{Literature review}

Past studies have employed a mixture of methodologies and generally lack the comparable and reproducible models and data inputs that are necessary to assess renewable energy in Mexico and hinder a direct comparison of assessments. In 1995, the first national onshore wind assessment was conducted by Schwartz et al. [15], in which regional wind zones with both high and poor potentials were identified and formed the basis of most of the subsequent regional wind energy assessments. For instance, Jaramillo et al. [16] concluded that in the federal state of Baja California, a good wind region identified by Schwartz et al., the average levelized cost of electricity (LCOE) from onshore wind would be around 50 EUR/MWh. Later, in 2010, Hernández-Escobedo et al. [17] assessed the wind potential of the entire country, estimating that a modeled $750 \mathrm{~kW}$ turbine could operate with 1700 full load hours (FLH) on average. However, the corresponding LCOE was not provided and the model used was not open-source, which makes the findings difficult to compare. Subsequently, Hernández-Escobedo et al. [18] performed a similar analysis with a 1.5 MW wind turbine in the state of Veracruz. The result was an FLH estimation of around 1750-2630 hours per year. This second study did not include an LCOE estimation either. Likewise, the works of Figueroa-Espinoza et al. [19], Carrasco-Diaz et al. [20], Carreon-Sierra et al. [21], and Hernández-Escobedo [22] focused on different regions in Mexico, but again did not inclue detailed techno-economical parameters in their results. In 2019, Rodriguez-Hernández et al. [23] employed yet another methodology to assess the economic feasibility of small wind turbine designs in the Mexico City region and reported that only turbines with capacities of 0.5 and $0.8 \mathrm{~kW}$, which are not in line with recent and 
future trends in utility-scale onshore wind turbines [24], could be economically viable in the region.

Most assessments hitherto have only focused on onshore wind potential and to the authors' knowledge, only one study, the "National inventory of zones with high potential for clean energy" (AZEL) [25], estimates open-field photovoltaics (PV) potential in the country. Furthermore, to the best of the authors' knowledge, offshore wind energy and rooftop PV have not yet been assessed on a national level. The AZEL assessment carried out by the National Ministry of Energy (SENER) consists of estimations of renewable energy potential based on an energy density analysis presented via a geographic information system (GIS) map of onshore wind and open-field solar PV among others. Although the AZEL report is the first assessment to offer some land exclusion constraints for the placement of PV parks and onshore turbines, such as protected areas, human settlements, transportation roads, transmission lines, minimum continuous areas, 1 terrain elevation, airports, coastal lines, and minimum wind speed, it does not provide techno-economical details on the costs of electricity production. The AZEL report also fails to provide time-series generation profiles, account for efficiency gains over time due to technology advancement, offer the optimal arrangement of VRES installations, or the cost functions that are necessary to more precisely estimate green potential.

Internationally, relevant renewable energy assessments have incorporated complementary considerations and progressively improved in their accuracy and standardization. McKenna et al. [26] modeled onshore wind potential for Germany using wind speed data with a $1 \mathrm{~km}^{2}$ spatial resolution, multiple wind turbine designs, and a detailed land eligibility analysis (LEA). Building on McKenna's approach, Jäger et al. [27] assessed the onshore wind potential of Baden-Württemberg, Germany, positioning wind turbines according to the wind direction to maximize the utilization of the available land and accounting for wind-blocking from neighboring turbines. Staffell and Pfenninger [28] used NASA's MERRA-2 database [29] over 20 years to re-analyze previous wind power assessments and found that, depending on the weather of a particular year, wind assessments could differ by up to $50 \%$ in terms of capacity factors and total generation output. The researchers concluded that taking larger weather timespans could help reducing weather variability across different years. Robinius et. al [30], [31] also applied an LEA and turbine positioning algorithms in a wind assessment for Germany for an advanced onshore wind turbine as part of a 2050 energy system simulation of Germany. Later, Ryberg et al. [24], [32] assessed the onshore wind, open-field PV, and rooftop PV potential in Europe to investigate the occurrence of lulls in electricity production, incorporating and improving upon the cumulative progress of past approaches. Ryberg's study included an extended LEA [33], [34] and the modeling of futuristic onshore wind turbines [24] and advanced PV panels to account for technological progress in the foreseeable future [24], as well as a scalable VRES placement algorithm and a pseudo-physics-based algorithm to calculate the generation profiles and apply some air density and sunlight irradiation corrections. Finally, Caglayan et al. [35] adopted Ryberg's methodology to calculate the potential of offshore wind energy for Europe, also adding the investment cost estimation function described by Fingersh et al. [36] and Maness et al. [37], which is a function of foundation type, distance to shore, and ocean depth.

Due to the recent progress in the field not being applied to Mexico and given the large methodological divergences in previous assessments, this study aims to assess the techno-economical potential in the entire Mexican territory2 of four VRES: onshore wind,

1 Ignores the sparse land available for installations smaller than up to $12.5 \mathrm{~km}^{2}$. 
offshore wind, open-field PV, and rooftop PV for the future, 2050 context using a state-ofthe-art approach. The ultimate objective of this work is to provide practical information to facilitate decision-making by key stakeholders with respect to an optimal and sustainable energy system design. The study is structured as follows: Section 0 serves to introduce the relevance of the topic, after which the methodology is described in Section 0 . The results and discussion are presented in sections 0 and 0 , respectively. Finally, relevant conclusions are presented in Section 0.

\section{Methodology}

The selected assessment approach comprised three main steps. First, an extensive LEA was applied to Mexico, maintaining a particular emphasis on country-specific factors. The total eligible area per technology and were distribution are obtained here. Secondly, the maximum number of VRES installments with their techno-economic parameters were individually derived by applying local terrain-weather technology design correlations, as well as costing algorithms as utilized in the selected literature. Finally, quasiphysics-based renewable energy production simulations were carried out to obtain timeseries generation profiles for each installment. The average electricity generation, FLH, and LCOE were also calculated and the VRES techno-economic potential obtained by curtailing electricity production with an LCOE over 70 EUR/MWh that corresponds to historic average electricity costs in Mexico according to data reported by the National Electricity Control Authority [38]. A more detailed description of the three main steps in the methodology is presented in the subsequent subchapters. The results, discussion, and conclusions are structured in accordance with the administrative state division, as well as geographical zones (shown in Figure 1 to help the reader follow the comparisons more easily.

\section{1. . Land Eligibility Analysis}

The Geospatial Land Availability for Energy System (GLAES) model [39] developed by Ryberg et al. [34] was employed to determine the geospatially-constrained eligible land for the investigated VRES technologies. In total, 34 land constraints and their technologyspecific exclusion zones were considered. This large number of constraints was intended to underpin a conservative approach and avoid "environmental problem shifting" [40]. Table 4, in the appendix, lists the land constraints and exclusion zones in detail for onshore wind, offshore wind, and open-field PV. The LEA for rooftop PV was only constrained by human settlements (house rooftops) in accordance to Ryberg's approach [32]. For each technology, spatial reference system 6263 [41] was used with a spatial resolution of 100 $\mathrm{m}^{2}$, as it represents a good trade-off between spatial fidelity, data availability, and computational intensity. 
Figure 1. Mexican territorv bv state division and regional clasification.

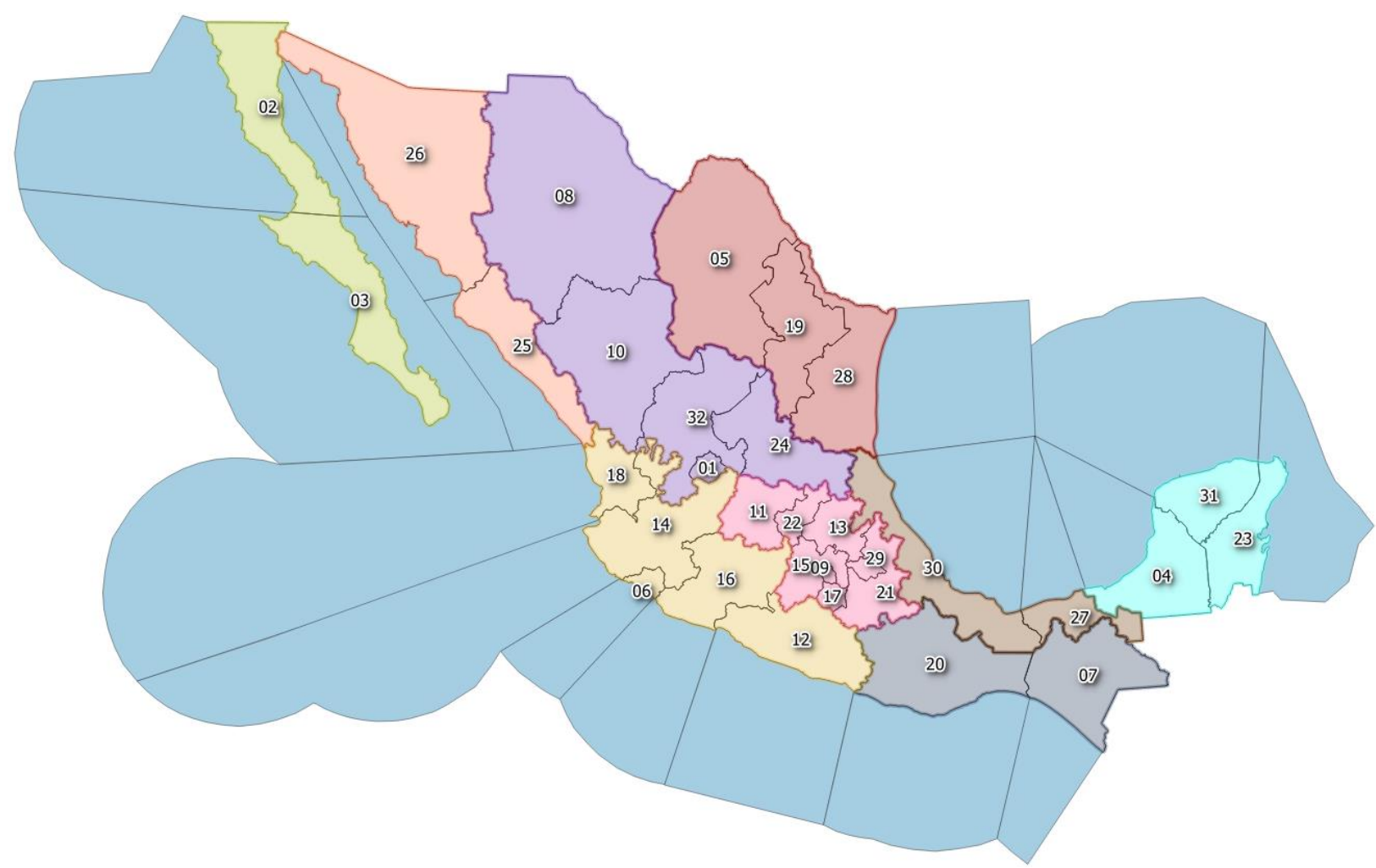

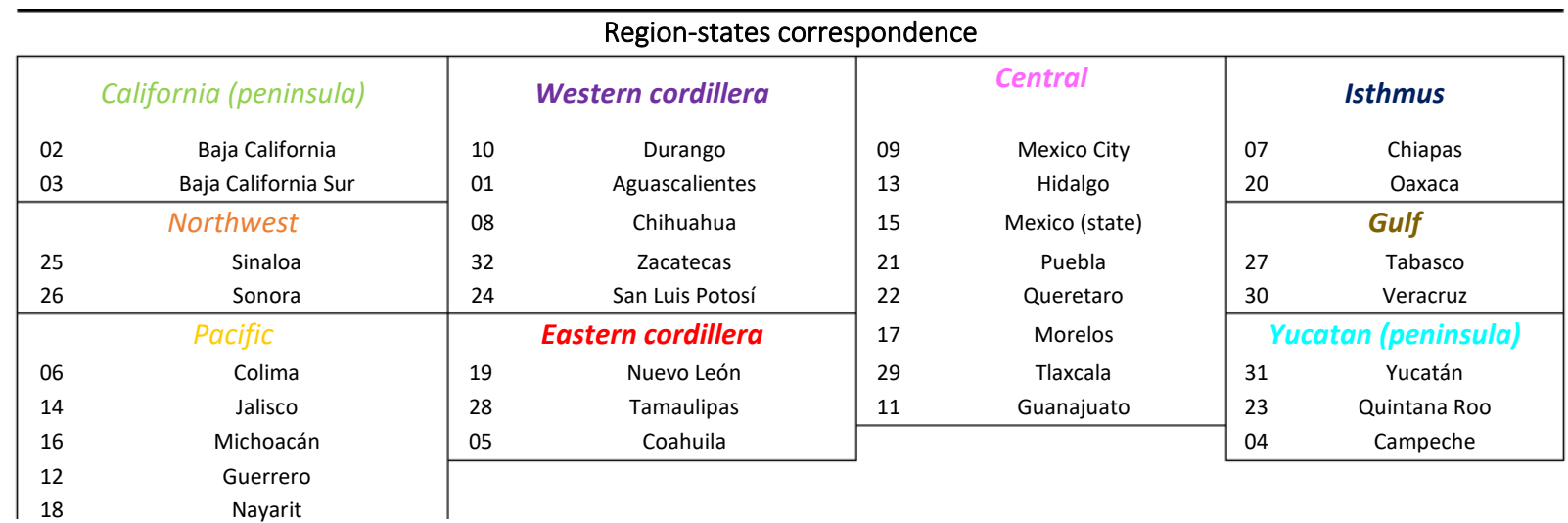

Of a total of 34 constraints, 27 were previously employed by either Ryberg et al. [32], Caglayan et al. [35], or Heuser et al. [42] and were kept unchanged because they do not conflict with the particularities of the Mexican context. Official datasets published by Mexican authorities were preferred when possible, as detailed in Table 4 in the appendix. Detailed justifications for the selection of these constraints, filtering procedures, and the buffer zones used can be found in the preceding works of Ryberg et al. [32], Caglayan et al. [35], and Heuser et al. [42], whereas the following subchapter describes in more detail the adjusted and additional considerations for the Mexican context.

\subsubsection{Mexico-specific LEA constraints}

Seven primary constraints specific to the context of Mexico are taken into account, and which constitute novel contributions of this work, namely: military areas, harbors, LNG terminals, geothermal sites, primary jungles, active volcanoes, and hurricanes. The reasons for their inclusion and the corresponding buffer zones assumed are also outlined. Details on the data sources and assumed buffer distances are included in Table 4 in the appendix. In general, international data sources were used, following Ryberg et al.'s [43] methodology for the most part. Nevertheless, data from national sources were preferred 
with respect to constraints relating to demographics, energy infrastructure, and land use, as they were generally more up to date than international data sources.

All VRES placements within $1 \mathrm{~km}$ of military areas, harbors, and LNG terminals were excluded due to the security issues entailed and the assumption that significant interference between VRES production and the operations conducted in these areas could occur. In a $200 \mathrm{~m}$ radius from geothermal sites, where geothermal energy systems can potentially be installed, placements were restricted to maintain the potential of this renewable energy source. Placements within primary jungles and within $1 \mathrm{~km}$ of their surrounding areas were excluded to protect biodiversity, as recommended by the SENER's environmental evaluation [44]. Based on the conclusions of Capra et al. [45], circular exclusion areas with a radius of $2 \mathrm{~km}$ from active volcanoes' vents were excluded for onshore wind turbines and open-field PV parks to avoid the risks of volcanic activity. Offshore wind turbines were considered by the authors not to be subject to these risks, as they must be placed in water at least $15 \mathrm{~km}$ from coastlines [35], and no records of marine volcanic eruptions in those areas of Mexico could be found. Similarly, areas hit by hurricanes of category 3 or above, as per data from 1980 to 2019 by the US National Oceanic and Atmospheric Administration (NOOA) [43], were excluded for both wind turbine installation variants. Category 3 hurricanes have a maximum sustained wind speed above $60 \mathrm{~m} / \mathrm{s}$, in accordance with the limit of most commercial wind turbines' resistance $(40-80 \mathrm{~m} / \mathrm{s})$ [46]. The exclusion zone in this case is taken as $30 \mathrm{~km}$, as this is the maximum radius at which any hurricane has shown sustainable wind speeds above $60 \mathrm{~m} / \mathrm{s}$ [47]. This security buffer is increased to $50 \mathrm{~km}$ for PV installations where not only wind speeds but also flying objects can cause damage.

Land constraints such as radio towers, land instability (i.e., the likelihood of landslides), and ground composition considered by previous authors [48]-[50] were not included herein due to a lack of these data existing for Mexico. A minimum distance to a transmission line is not considered applicable in the case of Mexico in 2050, as the country's electricity demand is expected to grow considerably [11], adding the need for extensive grid expansion and, therefore, making the current status quo of connection not applicable to a 2050 context. Arguably, other LEA constraints such as earthquakes and tsunamis can potentially be included in an LEA for a country such as Mexico. Nevertheless, this study does not include these due to empirical evidence found in the literature and presented in appendix 0 .

\subsection{Techno-economic parameters}

Once the available areas had been obtained, GLAES was again used to place minimally-separated elliptical or polygonal geometries representing either single turbines or solar PV parks, respectively. Around 1.6 million elliptical shapes representing $136 \mathrm{~m}$-diameter onshore turbine rotors oriented towards the 39-years average wind direction were incorporated in the available land with an inter-turbine separation of $8 \times 4$ times the rotor diameter (transversal $x$ longitudinal axis) in accordance with Ryberg et al. [24]. Similarly, nearly 600,000 offshore turbines were modeled with a fixed rotor diameter of $210 \mathrm{~m}$ and separated by $10 \times 4$ times the rotor diameter, as per Caglayan et al. [35]. For PV technologies, polygonal shapes representing about 660,000 PV farms with several PV strings and $20 \mathrm{~km}^{2}$ of PV-covered house roofs were assigned, following Ryberg's [32] approach. Next, the technology design parameters were obtained. Futuristic onshore wind turbine design incorporated in the Renewable Energy Simulation toolkit (RESKit) for Python [51], and developed by Ryberg et al. [24] for a 2050 context, were used to account for technological development. Utilizing this algorithm, design parameters such as hub height and specific capacity were inferred for each turbine from local wind speed and terrain characteristics for a given rotor diameter. When applied to the previously obtained placements, onshore turbine designs resulted in nominal capacities and hub heights ranging from 3.2 to $5.9 \mathrm{MW}$ and 88 to $185 \mathrm{~m}$, respectively. Individual onshore turbines' total capital costs (CAPEX), ranging from 1090 to $1350 \mathrm{EUR} / \mathrm{kW}$, were obtained according to the costing 
procedure used by the same author. In it, a future 1,100 EUR/kW baseline cost design was assumed and assumed to cover the cost of capital, balancing of the system, and financial costs according to their CAPEX shares, suggested by NREL's turbine cost breakdown [52] and costing relationships noted by Fingersh et al. [36] and Maples et al. [53].

With respect to offshore wind, a fixed turbine design with a hub height of $135 \mathrm{~m}$, rotor diameter of $210 \mathrm{~m}$, and capacity of 9.4 MW was selected following the approach of Caglayan et al. [35]. The only design parameter used to select offshore turbines was the foundation type that yielded the lowest LCOE of the four investigated options, i.e., monopole, jacket, semisubmersible, and floating spar according to the placement criteria used by Maness et al. [37]. Similar to their onshore counterparts, the CAPEX cost function of offshore turbines uses a 2,300 EUR/ $\mathrm{kW}$ baseline design, resulting in a range of 1,570$10,000 \mathrm{EUR} / \mathrm{kW}$ due to cost additions arising from foundation type, sea floor depth, and distance to shore [35].

1. Table 1. VRES techno-economic parameters used.

\begin{tabular}{|c|c|c|c|c|c|}
\hline Parameter & Onshore turbines & Offshore turbines & Open-field PV & Rooftop PV & Units \\
\hline Capacity or Model & [3.2-5.9] $\mathrm{MW}^{*}$ & $9.4 \mathrm{MW}$ & $\begin{array}{c}\text { Winaico WSx-240P6 } \\
\text { (fixed-tilt) }\end{array}$ & LG 360Q1C-A5 & - \\
\hline CAPEX & {$[1,090-1,350]^{*}$} & {$[1,570-10,000]^{*}$} & 500 & 800 & $\mathrm{EUR} / \mathrm{kW}$ \\
\hline OPEX & 2 & 2 & 1.7 & 1.7 & $\%$ of CAPEX \\
\hline Economic life & 20 & 25 & 25 & 25 & years \\
\hline Hub height & {$[88-185]^{*}$} & 135 & - & - & $\mathrm{m}$ \\
\hline Rotor diameter & 136 & 210 & - & - & $\mathrm{m}$ \\
\hline Efficiency & - & - & 24 & 30 & $\%$ \\
\hline Technology & - & - & Polycrystalline & Mono-crystalline & - \\
\hline Area coverage & {$[185-100]^{*}$} & 187 & 20 & 6.67 & $\mathrm{~m}^{2} / \mathrm{kW}$ \\
\hline WACC & 0.08 & 0.08 & 0.08 & 0.08 & - \\
\hline Reference & [24] & [35] & [32] & [32] & \\
\hline
\end{tabular}

${ }^{*}$ Range of values obtained by applying individual local terrain-weather technology design correlations and costing algorithms incorporated in RESKit [51].

For PV technologies, the models Winaico WSx-240P6 (fixed-tilt) for open-field and LG 360Q1C-A5 for rooftops were selected, in accordance with Ryberg's methodology [32]. The tilt and azimuth angles were obtained on the basis of the Global Solar Atlas (GSA) [54] database for each PV park location, whereas the CAPEX assumptions correspond to 2050 projections by the Fraunhofer Institute [55] of $500 \mathrm{EUR} / \mathrm{kW}$ for open-field PV and 800 EUR/kW for rooftop PV modules. As in the case of wind turbines, PV CAPEX are assumed to cover all costs associated with installation. Furthermore, the technical parameters of the PV models were derived from the Go Solar California database [56], with a projected module efficiency of $24 \%$ and $30 \%$ for open-field and rooftop PV, respectively, as per the conservative projection for 2050 in the same Fraunhofer report.

The technologies' annual operational costs (OPEX) as percentages of their CAPEX and economic service lives were kept the same, as suggested by the corresponding costing methodology. The weighted average cost of capital (WACC) was fixed at $8 \%$ for all technologies to maintain consistency with similar assessments [24], [42], [57]. Regional differences in technology costs and access were not considered in the costing procedure. Nevertheless, the technology costs cited here are around $20 \%$ higher than those utilized by Sarmiento [58] for Mexico in the same 2050 context and, hence, represent a conservative approach. Table 1 summarizes the VRES techno-economic parameters utilized.

\subsection{VRES simulations and techno-economic potential}


The computational quasi-physics-based model Renewable Energy Source toolkit (RESKit) [51] was employed to simulate VRES production according to localized climate inputs and geospatial-specific characteristics, as per the methodology of Ryberg et al. [24] for onshore wind and PV potentials, and observing the methodology of Caglayan et al. [35] for offshore wind energy. A general description of the simulation procedure is offered here, but the reader is highly encouraged to refer to the original sources for more detailed information.

For onshore and offshore wind simulations, 39 years of available MERRA-2 weather data (1980-2019) from NASA [29] was processed to obtain the long-term 50 m-height wind speed values at a $50 \mathrm{~km}^{2}$ spatial resolution. Onshore turbines were then adjusted to local contexts by using the global wind atlas (GWA) [59] to further improve the spatial resolution to $1 \mathrm{~km}^{2}$. Then, local wind speeds were projected to the turbines' hub height using the roughness length factors estimated by Silva et al. [60] for the terrain type specified in the Corina Land Cover (CLC) dataset [61]. Offshore wind simulations utilize a constant $0.0002 \mathrm{~m}$ roughness lengths factor with a bilinear interpolation according to Caglayan et al. [35]. Subsequently, ideal gas air density was adjusted at the hub height by extracting the surface pressure and air temperature values from the MERRA-2 dataset, as suggested in IEC 61400-12 [62]. Finally, to account for stochastic wind energy losses, local wind speed values at the hub height were convoluted into synthetic power curves that were derived for each turbine as a function of its specific power. In this manner, the corresponding capacity factor at each hour in the weather data was obtained. The total annual generation and FLH were obtained by applying the simulations across the 39 years of data. The mean annual production and LCOE obtained represent historical averages over the evaluated time period.

For PV simulations, RESKit utilizes the already defined PV system location, module characteristics, and tilt and azimuth angles alongside weather data parameters such as air and dew point temperature near the surface, surface pressure, and near-surface wind speed. The model then outputs the capacity factors at each time step as a result of a multistep process. First, the solar position is computed for each time step at each location using the NREL Solar Position Algorithm [63], for which the terrain elevation obtained from the Global Multi-resolution Terrain Elevation Data [64] and pressure and temperature values from MERRA-2 are required. Then, extraterrestrial irradiance, relative air mass, and global horizontal irradiance (GHI) values at each time step were estimated as proposed by Spencer [65], Kasten and Young [66], and Perez et al. [67], respectively. Next, due to its lower spatial resolution, the adjustment procedure used for the wind simulations were applied to the obtained GHI values with the global solar atlas (GSA) [54]. Subsequently, the plane of array (POA) as a sum of its components' contributions (beam, ground-reflected, and sky-diffuse) was computed in accordance with the methodology of Myers [68] and Perez et al. [69], [70] and modified according to their respective angles of incidence according to De Soto [71] and Brandemuehl and Beckman [72]. Next, the cell temperature of the module was determined considering POA irradiance, wind speed, and air temperature with the method outlined by King et al. [73]. Afterwards, the DC electricity generation time series by the module was estimated as per the Single Diode model [71]. Finally, an $18 \%$ holistic loss was applied to account for inversion, wiring, soiling, and other losses according to values reported in the literature [54], [74]. For more information about the PV simulation procedure, the reader is encouraged to refer to the original source [57].

Like any other resource, VRES generation potential is constrained by technological development (technical potential) but also by its cost of production (economic potential) [75]. Based on the relationship between VRES market value3 and historical electricity 
prices4 proposed by Hirt [76], an LCOE cost5 threshold of 70 EUR/MWh based on past electricity prices in Mexico [38] was applied to distinguish techno-economic VRES potential. The logic behind this assumption was that electricity production with costs higher than the electricity price would not be economically-viable. The authors are of the view that comparing the electricity price to the LCOE is adequate as an initial approach to determining economic VRES potential.

\section{Results}

The results for land availability, VRES simulations, and VRES techno-economic potentials are presented in the following subchapters.

\subsection{Land availability}

Error! Reference source not found. displays the area eligible for the placement of wind turbines. Around $754,000 \mathrm{~km}^{2}$ of land $(\sim 39 \%$ of the total) is eligible for onshore installations. Most of it is in the country's northern states, where there are vast areas of uninhabited land and, to a lesser extent, in the southeastern states. The center of the country appears to have the least area eligible due to settlement-related constraints such as human habitation areas and roads. For offshore installations, a total area of around 183,000 km² ( $\sim 6 \%$ of the territorial sea) was found to be eligible. By comparison, the eligible area for offshore turbines is four times less than that for onshore ones. Most of this is allocated along the Gulf of Mexico and Yucatan peninsula, where shallow waters qualify as eligible despite being affected by hurricane-prone and conservation constraints. The Pacific coast features little eligible sea area due to the local arrangement of the tectonic plates that results in abrupt ocean depth drop-offs. The western side of the Baja California peninsula and the Isthmus coast partially escape this effect, as they do not lie along the inter-tectonic line.

Figure 2 displays two maps corresponding to the land eligible for the placement of PV technologies: A) for open-field PV; and B) for rooftop PV. Open-field PV parks account for a total area of around $578,000 \mathrm{~km}^{2}(\sim 30 \%$ of the territorial extension), which is around one quarter smaller than the eligible area for onshore wind.

Fion1re? Distrihıtion of availahle land for the nlacement of wind turhines.

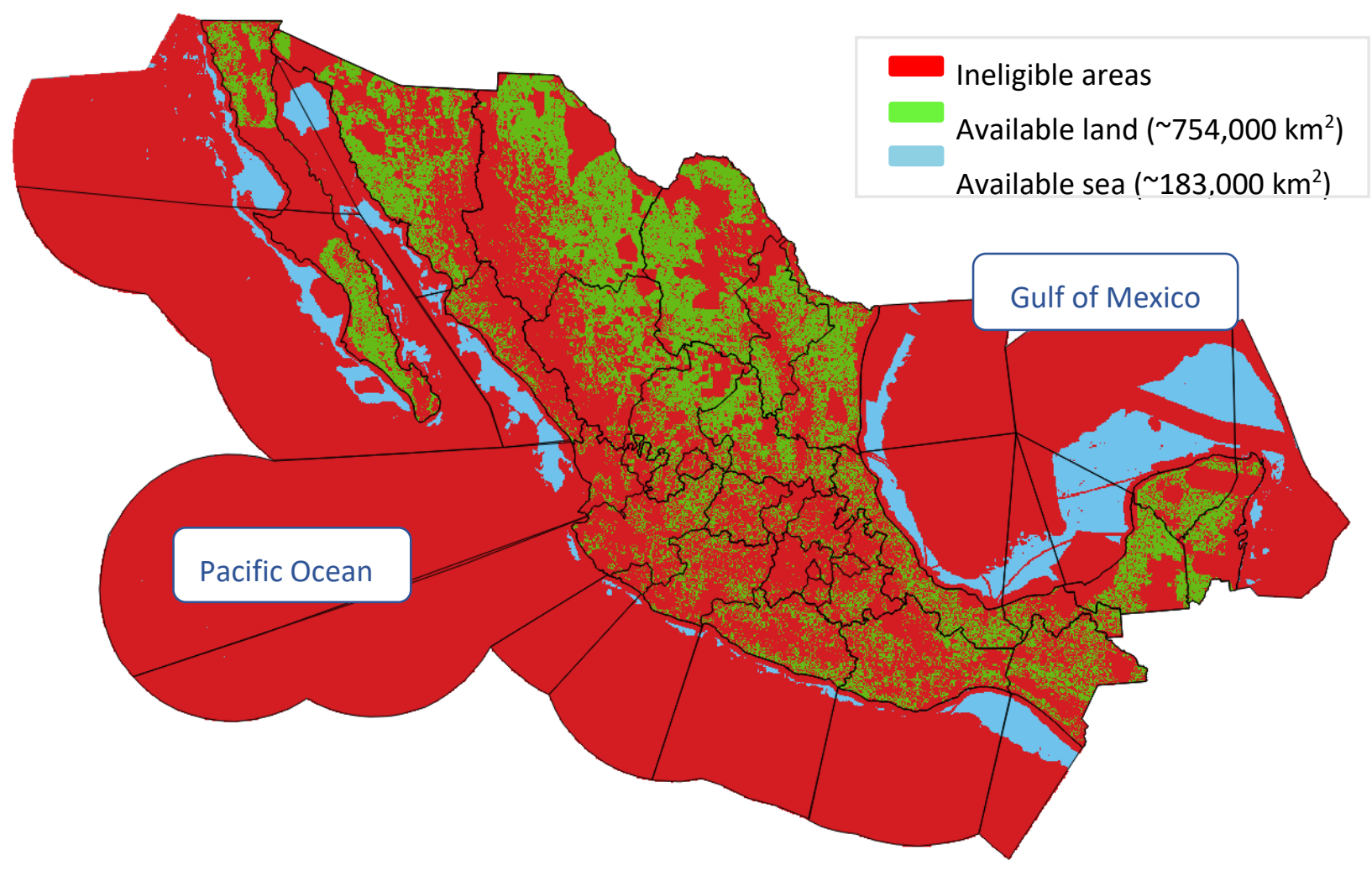


Figure 2. Distribution of available land for the placement of PV parks.

A) Open-field PV

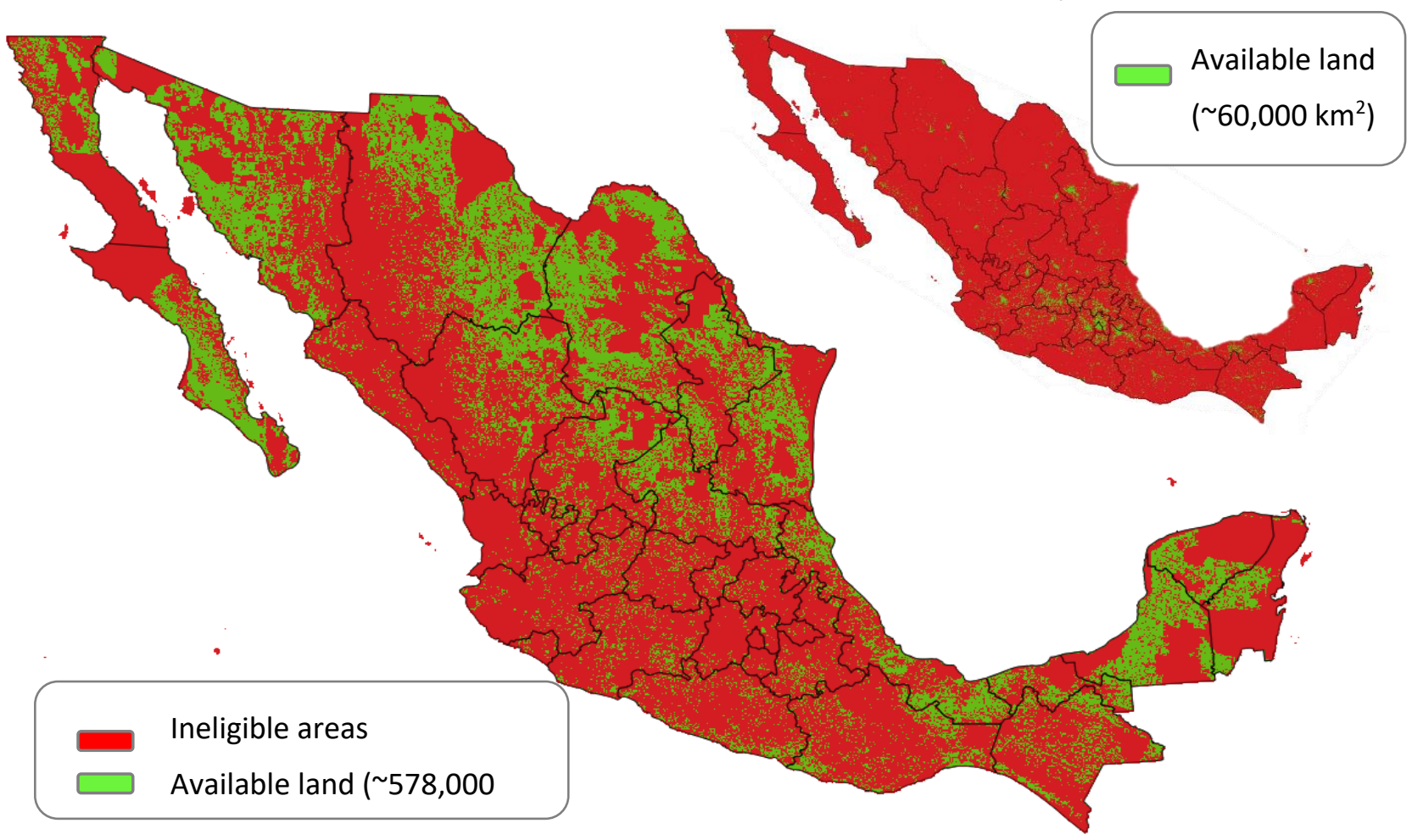

There are three main reasons for this difference. The first is that, given the mountainous geography of Mexico, tougher slope-related con straints (with a maximum inclination of $17^{\circ}$ for wind compared to $3^{\circ}$ for $\mathrm{PV}$ ) have a greater impact on the available land. Second, the larger exclusion zone for hurricane areas compared to that for wind turbines considerably reduces the eligible area in the Yucatan peninsula. Third, agricultural areas, which account for around $17 \%$ of the total territorial land, are excluded for PV installations but not for wind. The total eligible rooftop area is around $60,000 \mathrm{~km}^{2}$ and has a distribution focused in major urban areas across the country, especially in the central region.

\subsection{VRES techno-economic generation potential}

The overall annual techno-economic VRES generation potential of Mexico was found to be 54 PWh. Of this, 49.2 PWh derives from open-field PV (91\%) and 4.8 PWh from onshore wind $(9 \%)$. Offshore wind ( $38 \mathrm{TWh}$ ) and rooftop PV (1 TWh) generation represent less than $0.03 \%$ of the combined total. Despite having the largest available land share, the wind resources in Mexico are regionally-concentrated and less favorable by comparison to the solar ones with larger eligible areas that do not translate into higher generation potential. The following subchapters present the wind and PV potential distribution across the country, subdivided into the zones presented in Figure 1.

- Wind potential distribution

Figure 3 shows the 39-year average LCOE from 20 (the lowest LCOE yielded) to 70 EUR/MWh of onshore and offshore wind turbines. A white background is assigned to ineligible land.

Figure 3. Wind potential distribution.

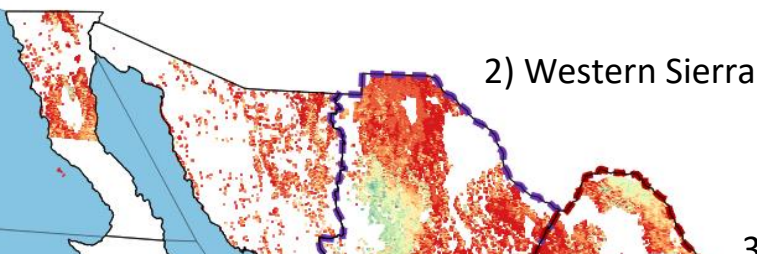


Four notable zones with good wind resources, all of which are mountainous, can be identified, namely: 1) The Isthmus (dotted in dark blue), where two different mountain systems create a gap that funnels and intensifies onshore wind resources towards the Pacific Ocean. This zone also covers some offshore wind potential. 2) The Western Sierra (dotted in purple), a chain of mountains that runs alongside the pacific coast through several northwestern states; 3 ) the Eastern Sierra (dotted in red), which is the eastern parallel with similar wind resources; and 4) a smaller area of offshore potential within the shallow waters of the Yucatan peninsula's eastern coastal line (dotted in light blue). Due to the geospatial dependence on mountains, slope-related constraints directly affect the wind potential adjacent to these regions. Some other good wind resources coincide with the coastal line of the Gulf of Mexico, and scattered locations in both peninsulas can also be highlighted. As some of these areas are protected for environmental reasons, turbine placement in them is bypassed and the remaining installations do not exhibit apparent clusters. Moreover, the turbine and grid infrastructure deployment needed to explore wind potential in those regions conflicts with environmentally-protected areas. Figure 4 also confirms that offshore wind zones not only offer less eligible area but also less technoeconomic potential than onshore sites. Relatively higher wind speeds in far-to-shore waters do not translate into cheaper LCOEs due to higher installation caused by increased sea floor depths and distance to the coast. Consequently, the most cost-attractive offshore zone is found near the coast of the Isthmus, where it partially benefits from the isthmus' wind funnel.

Figure 5 presents the wind capacity potential versus an LCOE of up to 70 EUR/MWh, grouped by zones. With the curtailment applied at 70 EUR/MWh, $15 \%$ of the VRES generation's installable capacity, pertaining almost exclusively to wind energy, was filtered out, but only $8 \%$ of the total VRES power output was reduced, which confirms that the filtered out wind turbines contribute only a small fraction of the generation potential. 
Figure 4 . Wind potential by zone according to the yielded LCOE.

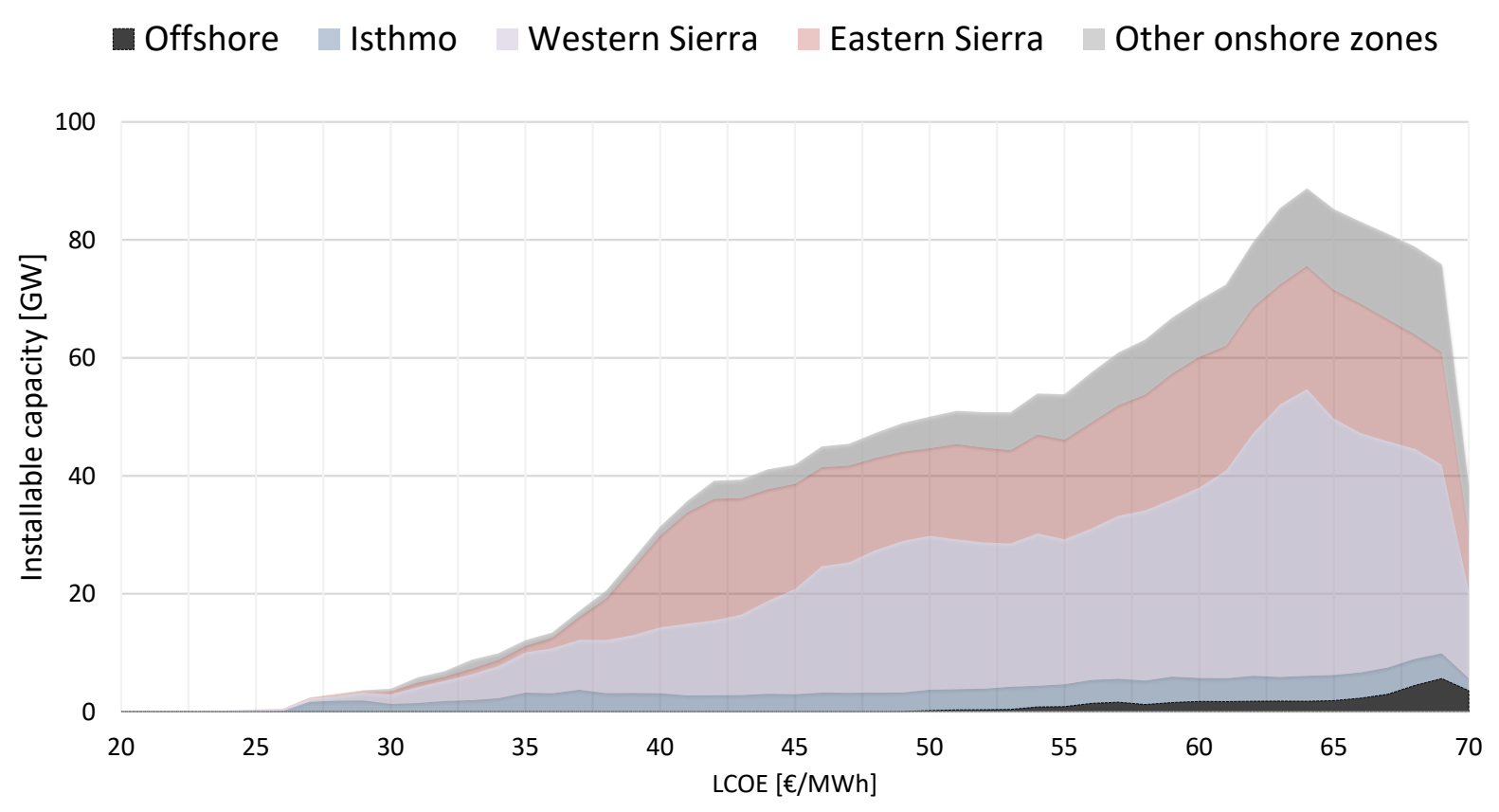

Despite being relatively small relative to the size of the country, the Isthmus contains around 53\% (6.5 GW) of all onshore capacity, with an estimated future LCOE equal to or less than $30 \mathrm{EUR} / \mathrm{MWh}$. This wind potential distribution confirms and explains why this zone alone contained around 90\% (1.8 GW) of the national wind capacity, as in 2019 [77]. The sunrise-facing Western Sierra (light purple) and Eastern Sierra (light red) uphills create high-speed wind corridors that can each accommodate up to $214 \mathrm{GW}$ of capacity (or $37 \%$ of the total) with an LCOE of 50 EUR/MWh or lower. By comparison, the smaller Isthmus zone comprises approximately $12 \%(63 \mathrm{GW})$ of the total capacity within the same LCOE range, whereas scattered onshore resources in the rest of the country (gray) make up the remaining $14 \%(83 \mathrm{GW})$. Similarly, offshore wind energy potential (in back) below 70 EUR/MWh of 92 GW (97\% of total) exist almost exclusively in the seas around the Isthmus and Yucatan peninsula.

Table 1 presents the values for capacity, hub height, FLH, and mean generation, corresponding to an average turbine design per geographical zone for various LCOE batches that could serve as a design reference for a results comparison, or as modeling parameters when an optimal wind turbine design algorithm is unavailable. For onshore installations, investments and mean generation electricity production are proportional to the turbines' baseline costs and FLH, respectively. In general, turbines in the Isthmus area have slightly larger capacities and lower hub heights due to the region's higher wind speeds compared to those in the Western and Eastern Sierras, which have similar designs because of the similar geographical features. As the LCOE threshold increases to 50 or $70 \mathrm{EUR} / \mathrm{MWh}$, average designs in the three zones tend to look similar until merging into a national average design occurs at $4.1 \mathrm{MW}, 125 \mathrm{~m}$ hub height, and $126 \mathrm{~m}$ rotor diameter. On the other hand, the FLHs exhibit a large deviation based on the zone. The FLH in the best locations, such as the Isthmus, are almost $45 \%$ bigger than the national average. Consequently, their LCOEs vary considerably, as noted in the previous figure.

Table 1. Average design characteristics of onshore wind turbines by zone and LCOE.

\begin{tabular}{c|cccccc}
\hline LCOE batch & \multirow{2}{*}{ Zones } & Average turbine & Hub height & FLH & Installable & Annual energy yield \\
[EUR/MWh] & capacity [MW] & {$[\mathrm{m}]$} & {$[\mathrm{h} /$ year] } & Potential [GW] & {$[\mathrm{TWh} / \mathrm{a}]$} & \\
\hline
\end{tabular}




\begin{tabular}{c|cccccc}
\hline \multirow{3}{*}{$(20-30]$} & Isthmus & 5.0 & 92 & 4550 & 7 & 30 \\
& Western Sierra & 4.8 & 98 & 4500 & 4 & 17 \\
& Eastern Sierra & 4.7 & 102 & 4500 & 1 & 6 \\
$(30-50]$ & Isthmus & 4.4 & 115 & 3250 & 57 & 190 \\
& Western Sierra & 4.4 & 115 & 3050 & 248 & 760 \\
& Eastern Sierra & 4.4 & 115 & 3050 & 212 & 650 \\
$(50-70]$ & Isthmus & 3.9 & 136 & 2350 & 81 & 190 \\
& Western Sierra & 4.1 & 125 & 2250 & 658 & 1500 \\
& Eastern Sierra & 4.1 & 125 & 2250 & 385 & 870 \\
\hline
\end{tabular}

Table 2 displays the average offshore turbine characteristics with an LCOE restricted to $70 \mathrm{EUR} / \mathrm{MWh}$ or lower by zone. As the offshore turbines were modeled with a fixed design (see Section 0.3), investment costs varied slightly from 19 to 20.8 million EUR due to the different contributions of the distance to shore, ocean depth, and foundation type on the costing function. Nevertheless, the resulting investment costs were around four times higher than those for onshore turbines, whereas the resulting mean generation was not proportionally higher. In fact, comparing the best locations, two onshore turbines could produce around $86 \%$ of the electricity output of one offshore turbine at around half $(52 \%)$ the installation cost. Therefore, the LCOE of offshore wind is considerably higher than onshore.

Table 2. Average design characteristics of offshore wind turbines by zone.

\begin{tabular}{c|ccccccc}
\hline $\begin{array}{c}\text { Zones where } \\
\text { LCOE } \leq\end{array}$ & $\begin{array}{c}\text { Distance to } \\
\text { shore }[\mathrm{km}]\end{array}$ & $\begin{array}{c}\text { Ocean depth } \\
{[\mathrm{m}]}\end{array}$ & $\begin{array}{c}\text { Foundation type } \\
\text { preference }\end{array}$ & $\begin{array}{c}\text { Investment } \\
\text { [million } \\
\text { EUR] }\end{array}$ & $\begin{array}{c}\text { FLH } \\
\text { [h/year] }\end{array}$ & $\begin{array}{c}\text { Installable } \\
\text { Potential } \\
\text { [GW] }\end{array}$ & $\begin{array}{c}\text { Annual energy } \\
\text { yield [TWh/a] }\end{array}$ \\
\hline Isthmus & 32 & 135 & Spar (66\%) & 20.8 & 4090 & 25 & 100 \\
Yucatan & 44 & 232 & Monopile (100\%) & 19 & 3385 & 40 & 150 \\
\hline
\end{tabular}

\section{PV potential and distribution}

Figure 5 shows the corresponding LCOE map for PV technologies. Overall, Mexico has large PV energy potential throughout the country. Nevertheless, two effects slightly affect this: the effect of latitude and tropical weather. PV LCOEs tend to be slightly more expensive as latitude increases due to fewer hours of sunlight throughout the year. Northern states in the proximity of the border to the U.S. (marked with a doted yellow line) have LCOEs of approximately $30 \mathrm{EUR} / \mathrm{MWh}$, whereas towards the center, the LCOEs are mostly around 25 EUR/MWh. Despite this latitude effect, the eligible area for PV parks in the northern states is much larger, which leads to increased solar potential. The tropical climate also affects PV panels. 


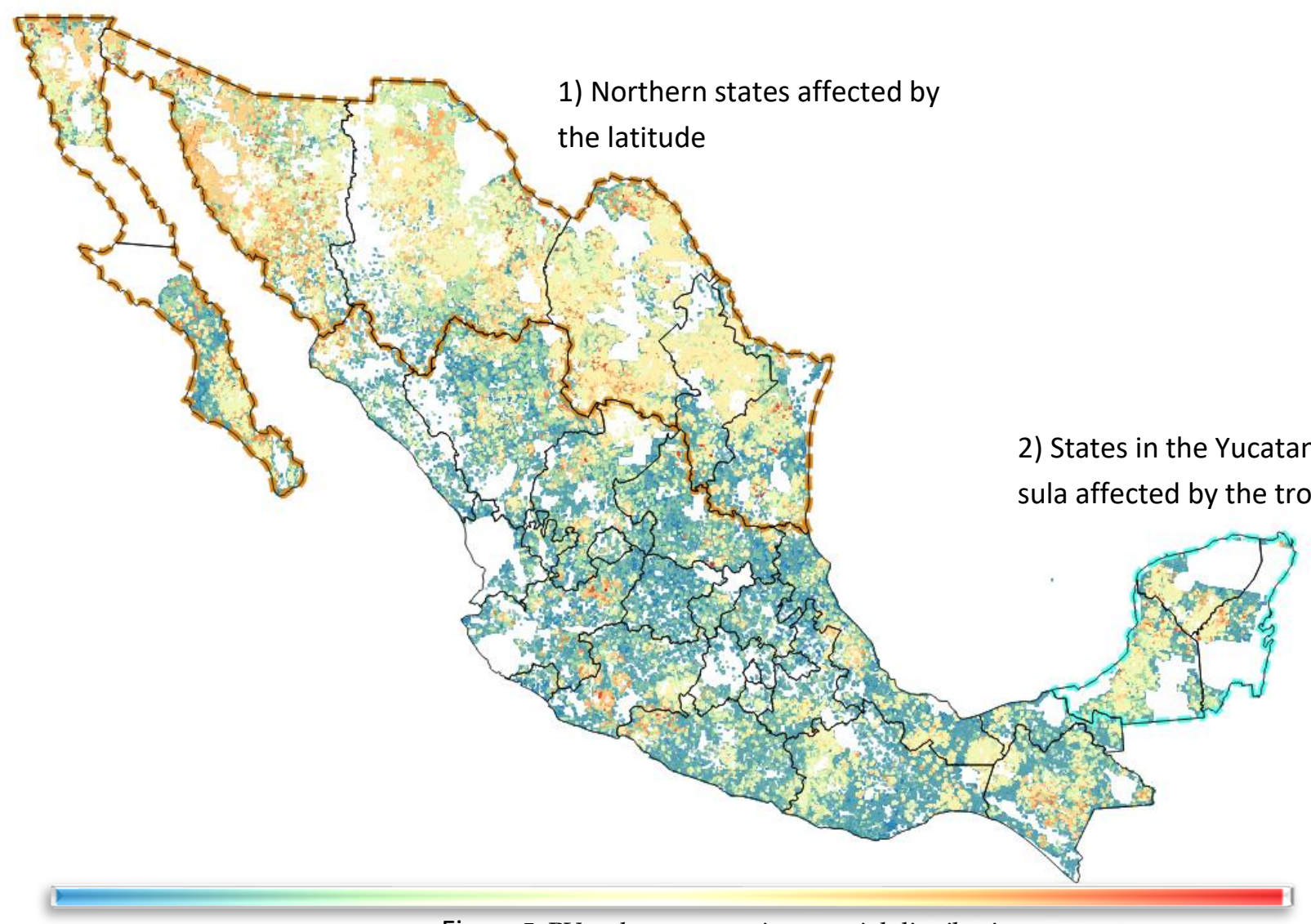

Figure 5. PV techno-economic potential distribution.

In contrast to the latitude effect, the climate in the Yucatan peninsula and most of the states along the coasts (marked by dotted blue lines) are subject to more rain and clouds that cause less FLH and therefore increase the LCOE. As there is no fundamental modeling difference between PV technologies, rooftop PV exhibits higher LCOEs than openfield due to the CAPEX difference and sub-optimal orientations. Its total potential is negligible compared to open-field PV.

Figure 6 presents the PV capacity potential by LCOE and grouped into zones. Because of the PV potential's direct dependency on the amount of eligible land, zones with larger areas have greater PV potential. Accordingly, the northern zones, such as the Western Sierra, Eastern Sierra, and Northwest, have the greatest potential. 90\% (20.8 TW) of the national capacity is within 24 and $30 \mathrm{EUR} / \mathrm{MWh}$ and $41 \%(9.6 \mathrm{TW})$ is found at an LCOE equal to or below $25 \mathrm{EUR} / \mathrm{MWh}$. All of the zones exhibit installable capacity in all of the LCOE ranges. 
Figure 6. PV potential by zone according to the yielded LCOE.

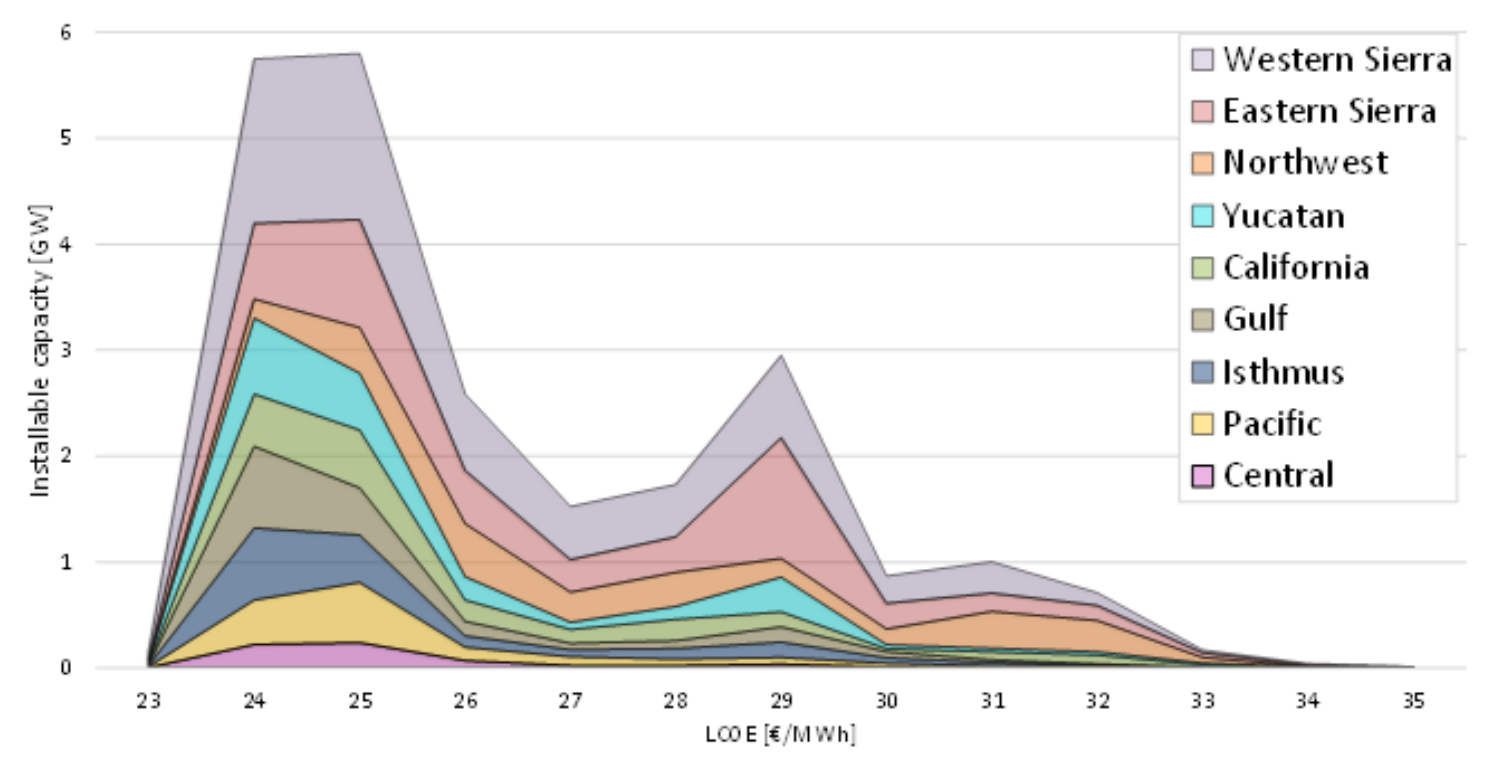

A different way to look at the PV potential is by considering PV parks' FLH as a proportion of the total potential by zone, as presented in Figure 7 . This makes it apparent that $2300 \mathrm{FLH}$ is the predominant condition nationally, which explains the good PV generation potential across the country. On the other hand, it also indicates that within zones, there is a large difference between the highest and lowest FLH yields. Differences of around 800 to $500 \mathrm{FLH}$ or $12 \mathrm{EUR} / \mathrm{MWh}$ between the best and worst locations can be seen in the California peninsula or the Gulf of Mexico respectively, influenced by the particular local conditions, such as irradiance or temperature. The latitude effect discussed in Section 0.3 on the PV potential is even more clearly shown. The northern zones, by contrast, such as the northwestern $8 \%$ of the placements, yield $2300 \mathrm{FLH}$, whereas in more central zones, such as the Gulf, Isthmus, or Central, the share of the same FLH batch is over $40 \%$. Similarly, the tropical weather effect also slightly reduces the share of this FLH batch in the Yucatan peninsula (37\%) compared to other zones at similar latitudes, such as the Central or Gulf ( $40 \%$ and $50 \%$, respectively) regions. Unlike the wind turbines simulation, PV technologies were simulated using a single PV model, and therefore a table with an average PV park design is not provided. 
Figure 7. PV full load hours by zone.

\begin{tabular}{|c|c|c|c|c|c|c|c|c|c|}
\hline \multirow{12}{*}{$\begin{array}{r}\text { Central - } \\
\text { Pacific - } \\
\text { Isthmus - } \\
\text { Gulf - } \\
\text { California - } \\
\text { Yucatan - } \\
\text { Northwest - } \\
\text { Eastern Sierra - } \\
\text { Western Sierra - }\end{array}$} & 0 & 0 & 1 & 8 & 5 & 8 & 36 & 40 & 2 \\
\hline & 0 & 2 & 3 & 6 & 7 & 9 & 38 & 35 & 1 \\
\hline & 0 & 1 & 4 & 11 & 7 & 7 & 22 & 47 & 1 \\
\hline & 0 & 0 & 3 & 11 & 4 & 8 & 22 & 50 & 1 \\
\hline & 1 & 5 & 5 & 10 & 11 & 12 & 27 & 28 & 1 \\
\hline & 0 & 2 & 3 & 18 & 5 & 9 & 24 & 37 & 1 \\
\hline & 0 & 11 & 19 & 9 & 14 & 23 & 17 & 8 & 0 \\
\hline & 0 & 4 & 7 & 28 & 9 & 11 & 22 & 19 & 0 \\
\hline & 0 & 2 & 7 & 15 & 10 & 13 & 24 & 28 & 1 \\
\hline & & & & & & & & & \\
\hline & 0 & 3 & 7 & 15 & 9 & 12 & 24 & 28 & 1 \\
\hline & 1600 & 1700 & 1800 & 1900 & 2000 & 2100 & 2200 & 2300 & 2400 \\
\hline
\end{tabular}

\section{Discussion}

This section will focus on differences from the most relevant previous VRES assessment and the implications of the methodology, concluding with possible ways by which the assessment can be further improved in the future.

By comparison to other VRES assessments in Mexico, only five of the regional studies mentioned in the literature review can be compared to some extent to this study due to their mixed, and sometimes unstated, methodologies. Jaramillo et al. [16] concluded that $750 \mathrm{~kW}$ wind turbines in Baja California Sur would operate on average for $2200 \mathrm{FLH}$, producing LCOEs from 40-60 EUR/MWh.6 In comparison, this assessment demonstrates an average of almost $3000 \mathrm{FLH}$ ( $25 \%$ more), with LCOEs ranging from 46-50 EUR/MWh. The results reported herein largely coincide with Jaramillo et al.'s, despite the latter having been arrived 15 years ago, and with vast differences in turbine design. Jaramillo et al. drew on comparable costs, such as a CAPEX of $1000 \mathrm{EUR} / \mathrm{kW}$ and OPEX equivalent to $1 \%$ of the CAPEX, with an additional five years of economic life. The CAPEX cost estimation function utilized here also includes costs associated with grid connection and balance of system costs that were not stated as considered in Jaramillo et al. and whose impact on the LCOE could offset the performance gains of future turbine designs. In another example, the assessment for the state of Veracruz by Hernández-Escobedo [18] deviates considerably from the results obtained in this assessment. The techno-economic average energy yield per turbine in this study in the same state increased by around $19 \%$ in comparison to the results of Hernández-Escobedo. However, if merely a simple state average, as reported by Hernández-Escobedo, is considered, a $60 \%$ yield reduction per turbine is seen here, despite the modeling of futuristic turbine designs. Further investigation and the reproducibility of Hernández-Escobedo's work is not possible, however, as it employs non-open source software. Furthermore, Hernández-Escobedo [22] also assessed another Mexican region, namely the Baja California peninsula, where a comparison was also not possible, as it is an ineligible area due to environmental protection constraints according to the LEA used in this study. RodriguezHernandez's [23] assessment of the area of Mexico City concluded that there is virtually no techno-economic wind potential, which is consistent with the findings of this study. The potentials in the AZEL assessment [25] are most comparable to those in this study. Table 3 summarizes the comparison between them. In general, the AZEL estimates the total installable capacity for both open-field PV and onshore wind. This is a direct consequence of the more extensive LEA employed here that significantly reduces the maximum 
installable VRES capacities compared to AZEL, which only considers 11 constraints for onshore and 13 for open-field PV. Therefore, the maximum installable capacities in the AZEL assessment appear to be larger. Nevertheless, when looking at FLH or generation per installment, in this study the performance always increased. The reason for this is that AZEL employed a power density factor to calculate national potential, whereas in this study the power generation was simulated for each VRES placement. Additionally, the improved VRES performance and optimal wind turbine designs were not considered in AZEL, which explains the poorer individual performance and reduces the potential gap between both assessments. Consequently, the generation and capacity potentials differ.

Table 3. VRES potential comparison against government estimates.

\begin{tabular}{|c|c|c|c|c|c|}
\hline Parameter & VRES & $\begin{array}{l}\text { AZEL } \\
\text { Scenario } 3\end{array}$ & $\begin{array}{l}\text { Techno-economic } \\
\text { potential } \\
\text { in this study }\end{array}$ & $\Delta[\%]$ & Possible reasons \\
\hline \multirow{2}{*}{$\begin{array}{l}\text { Capacity } \\
\text { [TW] }\end{array}$} & Open-field PV & 33.5 & 23.3 & -30 & \multirow{2}{*}{ More extensive LEA } \\
\hline & Onshore wind & 2.8 & 1.9 & -32 & \\
\hline \multirow{2}{*}{$\begin{array}{l}\text { Generation } \\
\text { [PWh] }\end{array}$} & Open-field PV & 60.6 & 49.2 & -32 & \multirow{2}{*}{$\begin{array}{l}\text { VRES simulation } \\
\text { procedure and } \\
\text { higher capacities }\end{array}$} \\
\hline & Onshore wind & 6.9 & 4.8 & -30 & \\
\hline \multirow{2}{*}{$\begin{array}{l}\text { FLHs } \\
{[\mathrm{h} / \text { year] }}\end{array}$} & Open-field PV & 1820 & 2118 & +16 & \multirow{3}{*}{$\begin{array}{l}\text { Improved VRES } \\
\text { performance }\end{array}$} \\
\hline & \multirow[b]{2}{*}{ Onshore wind } & 2465 & 2500 & +2 & \\
\hline $\begin{array}{l}\text { Generation per } \\
\text { turbine [GWh] }\end{array}$ & & 2.5 & 10.2 & +400 & \\
\hline
\end{tabular}

VRES assessments can also vary significantly due to a number of assumptions made by their authors in the LEA, VRES simulation procedure, or techno-economical parameters incorporated. With respect to the LEA, the conservative approach followed here prioritizes a large number of constraints and scarifying potential to offer some tolerance for the expanding nature of some constraints, whose final distribution cannot be predicted (e.g., the expansion of cities and settlements, etc.). Nevertheless, new constraints could gain relevance or current ones lose it as VRES technologies are progressively deployed and increasingly interact with other activities. Consequently, the area available for VRES installations and ultimately the VRES generation potential will change as environmental, physical, sociopolitical, and economic conditions do.

Another way to improve the assessment is by accessing higher quality data. Even though the most up-to-date databases were used herein, data measurements can always be improved in the future and return results that are more precise. Other unevaluated issues arising in this assessment are disruptive technologies that can totally change the power system by revealing new energy potentials. Unfortunately, no model can predict the occurrence of these, much less their consequences. Only foreseeable technological improvements on current designs through 2050 have been captured by the design of synthetic power curves for wind turbines and PV panels with improved performance, as estimated by Ryberg [32], are considered. Increasing the simulations' resolution (temporally and spatially) is beneficial for increasing the accuracy of the results, although its exact extent is not yet known. Hourly evaluation and $100 \mathrm{~m}$ spatial resolution is currently a widely accepted resolution for a country assessment, and can be performed in a 
reasonable amount of time due to its lower computational complexity. Local conditions, such as noise tolerance, shadows, or roughness-lengths are also left unevaluated as a trade-off.

\section{Conclusions}

In light of Mexico's VRES potential and distribution, several conclusions and recommendations can be drawn. First, open-field PV is by far the most abundant VRES in the country. In all locations, the LCOEs of PV are below the 70 EUR/MWh threshold due to the good level of overall irradiation throughout the country, as is outlined in Section 0. The energy output of this technology alone would be sufficient to satisfy 150 times the 2017 national demand. Based on the generally good PV potential across the country, its deployment is likely to be highly decentralized. The development of the power system should anticipate adequate legal, economic, and technological frameworks in order to make the best us of these. A revision of the applicability of the LEA constraints and buffer zones is also recommended to capture changes in social preferences over time towards wind and PV technologies.

Secondly, despite there being some locations in which electricity can be yielded at costs even lower than by open-field PV (see Figure 4), onshore wind has 10 times less generation potential. Nevertheless, onshore wind can still potentially produce around five times the 2017 national consumption, with $81 \%$ of this potential concentrated in three wind zones alone. This regional wind potential distribution and the fact that PV potential is available across the country leads to the conclusion that there must be a strong emphasis on the development of future energy infrastructure, such as transmission lines, energy storage, and even renewable fuel production in these wind energy-rich regions. Renewable energy infrastructure projects in these regions will benefit in terms of rate of use, permitting, land use, economies of scale, etc. from both renewable sources. Moreover, prioritizing these renewable energy projects could also help overcome the other two energy challenges, namely electricity access in remote areas and the meeting of Mexico's environmental commitments. Thirdly, the center of the country, where the political boundaries create smaller and more densely-populated areas, exhibit the less techno-economic VRES potential, which comes virtually exclusively from open-field PV at competitive prices. Mexico City, for example, exhibits no techno-economic wind potential, but around 260 MW of PV at 28 EUR/MWh. At the same time, the central regions have high power consumption rates, which could increase the proclivity to deploy the existing PV potential as soon as possible. For this reason, the implementation of a higher-resolution regional model is recommended, as well as a more region-specific analysis favoring optimal PV potential utilization.

Finally, the VRES distribution across the country also suggests that a dedicated system to produce renewable electricity without integrating it into the national energy system would be difficult to implement in Mexico due to interregional connections between states being unavoidable for large-scale renewable electricity production, especially for wind turbine installations. This suggests that an optimal energy system design should incorporate temporally-resolved generation time series to identify synergies between wind and solar resources, and could be of high value for strategic energy system planning in Mexico.

Funding: This work was supported by the fund, CONACYT-SENER "Sustentabilidad Energética" 2017 [grant number: 74489] and the Helmholtz Association under the Joint Initiative "Energy System 2050: A Contribution of the Research Field Energy."

Conflicts of Interest: The authors have no conflicts of interest to declare. 


\section{References}

[1] IRENA, “Renewable Energy Capacity Highlights 2020,” IRENA, p. 3, 2020.

[2] T. Ajadi et al., "Global Trends in Renewable Energy Investment," 2019.

[3] IEA, "Renewables 2019," International Energy Agency, 2019. .

[4] United Nations, "Adoption of the Paris Agreement," Conf. Parties its twenty-first Sess., 2015.

[5] The World Bank, “New country classifications by income level," The Data Blog, 2016.

[6] The World Bank, "GDP (current US\$)," 2019. https://data.worldbank.org/indicator/NY.GDP.MKTP.CD?view=chart (accessed Jun. 01, 2020).

[7] U.S. Census Bureau, "World Population," 2020. https://www.census.gov/popclock/print.php?component=counter (accessed Jun. 01, 2020).

[8] International Energy Agency, “Energy Policies Beyond IEA Countries: Mexico 2017," 2017. doi: 10.1787/9789264290242-en.

[9] Gobierno de México, “Estrategia Nacional de Cambio Climático," 2015. doi: 10.1017/CBO9781107415324.004.

[10] Union of Concerned Scientists, "Each country's share of CO2 emissions," Union of Concerned Scientists. 2019.

[11] Secretaría de Energía, Programa de Desarrollo del Sistema Eléctrico Nacional 2018 - 2032 (PRODESEN). 2018.

[12] Gobierno de México, “Plan Nacional de Desarrollo 2001-2006," 2001.

[13] United Nations, World population prospects 2019. 2019.

[14] J. Hawksworth and D. Chan, "The world in 2050: will the shift in global economic power continue?," PwC, 2015. .

[15] M. N. Schwartz and D. L. Elliott, "Mexico Wind Resource Assessment Project," 1995.

[16] O. A. Jaramillo, R. Saldana, and U. Miranda, “Wind power potential of Baja California Sur, México," Renew. Energy, 2004, doi: 10.1016/j.renene.2004.03.004.

[17] Q. Hernández-Escobedo, F. Manzano-Agugliaro, and A. Zapata-Sierra, "The wind power of Mexico," Renewable and Sustainable Energy Reviews. 2010, doi: 10.1016/j.rser.2010.07.019.

[18] Q. Hernández-Escobedo, F. Espinosa-Arenal, R. Saldaña-Flores, and C. Rivera-Blanco, "Evaluación del potencial eólico para la generación de energía eléctrica en el Estado de Veracruz, México," DYNA, 2012.

[19] B. Figueroa-Espinoza, P. Salles, and J. Zavala-Hidalgo, "On the wind power potential in the northwest of the Yucatan Peninsula in Mexico," Atmosfera, 2014, doi: 10.1016/S0187-6236(14)71102-6.

[20] M. Carrasco-Díaz, D. Rivas, M. Orozco-Contreras, and O. Sánchez-Montante, "An assessment of wind power potential along the coast of Tamaulipas, northeastern Mexico," Renew. Energy, 2015, doi: 10.1016/j.renene.2015.01.007.

[21] S. Carreón-Sierra, A. Salcido, T. Castro, and A. T. Celada-Murillo, "Cluster analysis of the wind events and seasonal wind circulation patterns in the Mexico City region," Atmosphere (Basel)., 2015, doi: 10.3390/atmos6081006.

[22] Q. Hernandez-Escobedo, "Wind energy assessment for small urban communities in the Baja California Peninsula, Mexico," Energies, 2016, doi: 10.3390/en9100805.

[23] O. Rodriguez-Hernandez, M. Martinez, C. Lopez-Villalobos, H. Garcia, and R. Campos-Amezcua, "Techno-economic feasibility study of small wind turbines in the Valley of Mexico metropolitan area," Energies, 2019, doi: 10.3390/en12050890.

[24] D. S. Ryberg, D. G. Caglayan, S. Schmitt, J. Linßen, D. Stolten, and M. Robinius, “The future of European onshore wind energy potential: Detailed distribution and simulation of advanced turbine designs," Energy, 2019, doi: 10.1016/j.energy.2019.06.052.

[25] Secretaría de Energía, "Atlas nacional de zonas con alto potencial de energías limpias (AZEL)," 2019. [Online]. Available: dgel.energia.gob.mx/azel/.

[26] R. McKenna, S. Hollnaicher, and W. Fichtner, "Cost-potential curves for onshore wind energy: A high-resolution analysis for Germany," Appl. Energy, 2014, doi: 10.1016/j.apenergy.2013.10.030.

[27] T. Jäger, R. McKenna, and W. Fichtner, "The feasible onshore wind energy potential in Baden-Württemberg: A bottom-up methodology considering socio-economic constraints," Renew. Energy, 2016, doi: 10.1016/j.renene.2016.05.013.

[28] S. Pfenninger, J. DeCarolis, L. Hirth, S. Quoilin, and I. Staffell, "The importance of open data and software: Is energy research lagging behind?," Energy Policy, vol. 101, no. December 2016, pp. 211-215, 2017, doi: 10.1016/j.enpol.2016.11.046.

[29] National Aeronautics and Space Administration, "Modern-Era Retrospective analysis for Research and Applications, Version 2." NASA Goddard Earth Sciences (GES) Data and Information Services Center (DISC)., 2019, [Online]. Available: https://disc.gsfc.nasa.gov/datasets?keywords=\%22MERRA-2\%22\&page=1\&source=Models\%2FAnalyses MERRA-2.

[30] M. Robinius et al., "Linking the power and transport sectors - Part 2: Modelling a sector coupling scenario for Germany," Energies, vol. 10, no. 7, pp. 1-23, 2017, doi: 10.3390/en10070957.

[31] M. Robinius, Strom- und Gasmarktdesign zur Versorgung des deutschen Straßenverkehrs mit Wasserstoff zur Versorgung des deutschen Straßenverkehrs mit Wasserstoff Von der Fakultät für Maschinenwesen der, vol. 300. 2015.

[32] D. S. Ryberg, "Generation Lulls from the Future Potential of Wind and Solar Energy in Europe," RWTH Aachen, p. 316, 2019.

[33] D. S. Ryberg, Z. Tulemat, D. Stolten, and M. Robinius, "Uniformly constrained land eligibility for onshore European wind power," Renew. Energy, 2020, doi: 10.1016/j.renene.2019.06.127.

[34] D. S. Ryberg, M. Robinius, and D. Stolten, "Evaluating land eligibility constraints of renewable energy sources in Europe," Energies, 2018, doi: 10.3390/en11051246.

[35] D. G. Caglayan, D. S. Ryberg, H. Heinrichs, J. Linßen, D. Stolten, and M. Robinius, “The techno-economic potential of offshore wind energy with optimized future turbine designs in Europe," Appl. Energy, 2019, doi: 10.1016/j.apenergy.2019.113794.

[36] L. Fingersh, M. Hand, and A. Laxson, "Wind Turbine Design Cost and Scaling Model," Nrel, 2006, [Online]. Available: https://www.nrel.gov/docs/fy07osti/40566.pdf. 
[37] M. Maness, B. Maples, and A. Smith, "NREL Offshore Balance-of- System Model NREL Offshore Balance-of- System Model," no. January, 2017, [Online]. Available: https://www.nrel.gov/docs/fy17osti/66874.pdf.

[38] Centro Nacional de Control de Energía, “Historia de precios de energía," 2017. 2017, [Online]. Available: https://www.cenace.gob.mx/SIM/VISTA/REPORTES/H_RepPreEnergiaSisMEM.aspx?N=29\&opc=divCssPreEnergia\&site=Pre cios de la energía/Precios de Nodos Distribuidos/MTR/Diarios\&tipoArch=C\&tipoUni=SIN\&tipo=Diarios\&nombrenodop=Precios de Nodos Distribuidos.

[39] D. S. Ryberg, “Geospatial Land Availability for Energy Systems (GLAES).” 2018, [Online]. Available: https://github.com/FZJIEK3-VSA/glaes.

[40] D. Van Hertem and M. Ghandhari, "Multi-terminal VSC HVDC for the European supergrid: Obstacles," Renewable and Sustainable Energy Reviews. 2010, doi: 10.1016/j.rser.2010.07.068.

[41] Klokan Technologies GmbH, “Coordinate Systems Worldwide,” 2020. https://epsg.io/6362.

[42] P. M. Heuser, D. S. Ryberg, T. Grube, M. Robinius, and D. Stolten, “Techno-economic analysis of a potential energy trading link between Patagonia and Japan based on CO2 free hydrogen," Int. J. Hydrogen Energy, 2019, doi: 10.1016/j.ijhydene.2018.12.156.

[43] D. S. Ryberg, M. Robinius, and D. Stolten, "Methodological Framework for Determining the Land Eligibility of Renewable Energy Sources," arXiv Prepr. arXiv1712.07840, 2017.

[44] Secretaría de Energía, “Evaluación ambiental y social evaluacion ambiental y social estratégica para el desarrollo eólico en el sur del istmo de Tehuantepec," pp. 1-33, 2015, [Online]. Available: https://www.gob.mx/cms/uploads/attachment/file/136647/18439_EASE_E_lico_Tehuantepec_Resumen_ejecutivo_espa_ol.pdf.

[45] L. Capra, J. C. Gavilanes-Ruiz, R. Bonasia, R. Saucedo-Giron, and R. Sulpizio, “Re-assessing volcanic hazard zonation of Volcán de Colima, México," Nat. Hazards, 2015, doi: 10.1007/s11069-014-1480-1.

[46] D. Weston, "Vestas scales up to 4.2MW," Wind. Mon., 2017, [Online]. Available: https://www.windpowermonthly.com/article/1437274/vestas-scales-42mw.

[47] K. R. Knapp, M. C. Kruk, D. H. Levinson, H. J. Diamond, and C. J. Neumann, “The international best track archive for climate stewardship (IBTrACS)," Bull. Am. Meteorol. Soc., 2010, doi: 10.1175/2009BAMS2755.1.

[48] P. Lejeune and C. Feltz, "Development of a decision support system for setting up a wind energy policy across the Walloon Region (southern Belgium)," Renew. Energy, vol. 33, no. 11, pp. 2416-2422, Nov. 2008, doi: 10.1016/j.renene.2008.02.011.

[49] I. J. Ramírez-Rosado, E. García-Garrido, L. A. Fernández-Jiménez, P. J. Zorzano-Santamaría, C. Monteiro, and V. Miranda, "Promotion of new wind farms based on a decision support system," Renew. Energy, vol. 33, no. 4, pp. 558-566, Apr. 2008, doi: 10.1016/j.renene.2007.03.028.

[50] K. Ummel and D. Wheeler, “Desert Power : The Economics of Solar Thermal Electricity Desert Power : The Economics of Solar Thermal Electricity For Europe , North Africa , and the Middle East," 2008. [Online]. Available: https://cgdev.org/sites/default/files/1417884_file_Desert_Power_FINAL_WEB.pdf.

[51] D. S. Ryberg and D. G. Caglayan, “RESKit - Renewable Energy Simulation toolkit for Python.” 2019, [Online]. Available: https://github.com/FZJ-IEK3-VSA/RESKit.

[52] T. Stehly, D. Heimiller, and G. Scott, “Cost of Wind Energy Review," Tech. Rep., no. February, pp. 23-40, 2016, [Online]. Available: https://www.nrel.gov/docs/fy18osti/70363.pdf.

[53] B. Maples, M. Hand, and W. Musial, "Comparative Assessment of Direct Drive High Temperature Superconducting Generators in Multi-Megawatt Class Wind Turbines," Energy, 2010, doi: 10.2172/991560.

[54] Solargis s.r.o. and the World Bank Group, “Global Solar Atlas 2.0, a free, web-based application is developed and operated by the company Solargis s.r.o. on behalf of the World Bank Group, utilizing Solargis data, with funding provided by the Energy Sector Management Assistance Program (ESMAP). Fo," 2019. [Online]. Available: https://globalsolaratlas.info.

[55] Fraunhofer ISE, “Current and Future Cost of Photovoltaics," Agora Energiewende, 2015, doi: 059/01-S-2015/EN.

[56] Alexandre Edmond Becquerel, "History of Solar Energy in California - Go Solar California," 2006-2016, 2006. .

[57] D. S. Ryberg, "Generation Lulls from the Future Potential of Wind and Solar Energy in Europe," 2019.

[58] L. Sarmiento, T. Burandt, K. Löffler, and P. Y. Oei, "Analyzing scenarios for the integration of renewable energy sources in the Mexican energy system - an application of the Global Energy System Model (GENeSys-MOD)," Energies, 2019, doi: 10.3390/en12173270.

[59] Technical University of Denmark and the World Bank Group., "Global Wind Atlas 3.0, a free, web-based application developed, owned and operated by the Technical University of Denmark (DTU). The Global Wind Atlas 3.0 is released in partnership with the World Bank Group, utilizing data provided by Vortex, using fundi," 2019. [Online]. Available: https://globalwindatlas.info/.

[60] J. Silva, C. Ribeiro, and R. Guedes, "Roughness length classification of corine land cover classes," 2007.

[61] Copernicus (European Union's Earth Observation Programme), “Corine Land Cover (CLC) 2000, Version 2018." Copernicus, 2018, [Online]. Available: http://land.copernicus.eu/pan-european/corine-land-cover/clc-2000/view.

[62] International Electrotechnical Commision (ICE), “IEC 61400-12-1:2017.” p. 558, 2017, [Online]. Available: https://webstore.iec.ch/publication/26603.

[63] I. Reda and A. Andreas, "Solar Position Algorithm SPA," Natl. Renew. Energy Lab. Tech. Rep., 2008, doi: 10.2172/15003974.

[64] D. B. Danielson, J.J., Gesch, “Global Multi-resolution Terrain Elevation Data 2010 (GMTED2010),” 2011.

[65] J. W. Spencer, "Fourier Series Representation of the Position of the Sun," Search, 1971.

[66] F. Kasten and A. T. Young, "Revised optical air mass tables and approximation formula," Appl. Opt., 1989, doi: 10.1364/ao.28.004735. 
[67] R. R. Perez, P. Ineichen, E. L. Maxwell, R. D. Seals, and A. Zelenka, “Dynamic global-to-direct irradiance conversion models," 1992.

[68] D. R. Myers, Solar radiation: Practical modeling for renewable energy applications. 2017.

[69] R. Perez, P. Ineichen, R. Seals, J. Michalsky, and R. Stewart, "Modeling daylight availability and irradiance components from direct and global irradiance," Sol. Energy, 1990, doi: 10.1016/0038-092X(90)90055-H.

[70] R. Perez, R. Seals, P. Ineichen, R. Stewart, and D. Menicucci, “A new simplified version of the perez diffuse irradiance model for tilted surfaces," Sol. Energy, 1987, doi: 10.1016/S0038-092X(87)80031-2.

[71] W. De Soto, S. A. Klein, and W. A. Beckman, "Improvement and validation of a model for photovoltaic array performance," Sol. Energy, 2006, doi: 10.1016/j.solener.2005.06.010.

[72] M. J. Brandemuehl and W. A. Beckman, "Transmission of diffuse radiation through CPC and flat plate collector glazings," Sol. Energy, 1980, doi: 10.1016/0038-092X(80)90320-5.

[73] D. L. King, W. E. Boyson, and J. A. Kratochvil, "Photovoltaic array performance model," Sandia Rep. No. 2004-3535, 2004, doi: 10.2172/919131.

[74] S. Pfenninger and I. Staffell, "Long-term patterns of European PV output using 30 years of validated hourly reanalysis and satellite data," Energy, 2016, doi: 10.1016/j.energy.2016.08.060.

[75] P. Zweifel, A. Praktiknjo, and G. Erdmann, Energy Economics: Theory and Applications. 2017.

[76] L. Hirth, "The market value of variable renewables. The effect of solar wind power variability on their relative price," Energy Econ., 2013, doi: 10.1016/j.eneco.2013.02.004.

[77] El Financiero, "Parques eólicos en México," Mexico City, p. 1, 2019.

[78] I. Lavassas, G. Nikolaidis, P. Zervas, E. Efthimiou, I. N. Doudoumis, and C. C. Baniotopoulos, "Analysis and design of the prototype of a steel 1-MW wind turbine tower," Eng. Struct., 2003, doi: 10.1016/S0141-0296(03)00059-2.

[79] U. Ritschel, I. Warnke, J. Kirchner, and B. Meussen, “Wind turbines and earthquakes,” 2nd World Wind Energy Conf., 2003.

[80] R. W. Clough and J. Penzien, Dynamics of Structures, Third Edition. 2013.

[81] S. Øye, "Dynamic stall simulated as time lag of separation." Proceedings of the 4th IEA Symposium on the aerodynamics of wind turbines, 1991.

[82] H. Herrmann and H. Bucksch, "Eurocode 8 - Design of structures for earthquake resistance," in Dictionary Geotechnical Engineering/Wörterbuch GeoTechnik, 2014.

[83] E. I. Katsanos, S. Thöns, and C. Georgakis, "Wind turbines and seismic hazard: a state-of-the-art review," Wind Energy. 2016, doi: 10.1002/we.1968.

[84] N. Mimura, K. Yasuhara, S. Kawagoe, H. Yokoki, and S. Kazama, “Damage from the Great East Japan Earthquake and Tsunami - A quick report," Mitig. Adapt. Strateg. Glob. Chang., 2011, doi: 10.1007/s11027-011-9297-7.

[85] Takashi Matsunobu, Shinzo Inoue, Yoshiyuki Tsuji, Kenji Yoshida, and Mamoru Komatsuzaki, "Seismic Design of Offshore Wind Turbine Withstands Great East Japan Earthquake and Tsunami,” J. Energy Power Eng., 2014, doi: 10.17265/19348975/2014.12.007.

[86] S. Bhattacharya and K. Goda, "Use of offshore wind farms to increase seismic resilience of Nuclear Power Plants," Soil Dyn. Earthq. Eng., 2016, doi: 10.1016/j.soildyn.2015.10.001.

[87] O. Kübler, D. Renggli, S. Meyer, and G. Benz, “Wind farms: harvesting energy on shaky grounds and in stormy seas,” 2013. [Online]. Available: http://www.swissre.com/library/expertise-publication/Mind_the_risk_a_global_ranking_of_cities_un-.

[88] AMEE, “Panorama General de la Energía Eólica en México," 2010. [Online]. Available: https://amdee.org/Amdee/AMDEE_presentacion_esp.pdf.

[89] El Financiero, “Sismos 'noquean' a energía eólica," 2017, [Online]. Available: https://www.elfinanciero.com.mx/economia/sismos-noquean-a-energia-eolica.

[90] K. Schulle, "Earthquake's Effect on the Solar Energy Industry," Seek. Alpha, 2011, [Online]. Available: https://seekingalpha.com/article/258262-earthquakes-effect-on-the-solar-energy-industry.

[91] Instituto Nacional de Estadística Geografía e Informática (INEGI), “Marco Geoestadístico Nacional.” 2017, [Online]. Available: https://www.inegi.org.mx/temas/mg/.

[92] INEGI, "Conjunto de datos vectoriales de la carta de Uso del suelo y vegetación, escala 1:250000, serie VI (continuo nacional)," Uso de suelo y vegetación., 2014. .

[93] Osm2shp, “Open Street Maps shape files." [Online]. Available: http://osm2shp.ru/.

[94] Instituto Nacional de Estadística Geografía e Informática (INEGI), “Red nacional de caminos 2019," 2019. [Online]. Available: https://www.inegi.org.mx/temas/viascomunicacion/.

[95] Open Street Map (OSM), "Geofabrik Download Server," Geofabrik GmbH, 2018. .

[96] CIA, "Map of the World Oceans." https://www.arcgis.com/home/item.html?id=12c0789207e64714b9545ad30fca1633.

[97] National Oceanic and Atmospheric Administration, “Submarine cables 2019." 2019, [Online]. Available: https://data.noaa.gov/dataset/dataset/submarine-cables.

[98] Secretaria de Energía, "Inventario Nacional De Energías Limpias." 2017, [Online]. Available: https://dgel.energia.gob.mx/qa/INEL/INELV5/index.html.

[99] Mapcruzin, “Mexico shapefiles.” 2019, [Online]. Available: https://mapcruzin.com/free-mexico-maps.htm.

[100] Secretaría de Economía, “Mexico mining concessions." 2015, [Online]. Available: https://hub.arcgis.com/datasets/f4bebb67213b4d958938521691c97970_3. 
[101] Secretaría de Energía, “Infraestructura de Gas Natural en México." 2019, [Online]. Available: https://www.google.de/maps/d/edit?mid=1NQYs864qTUl5GKLecSY-8jY2h5u9EtVP\&ll=22.60802046476938\%2C$105.31052626045897 \& z=5$.

[102] Secretaría de Energía, “Mapa Energético de America del Norte." SENER, IEA, INEGI, 2019, [Online]. Available: http://gaia.inegi.org.mx/mdm-clientna/.

[103] Instituto Nacional de Estadística Geografía e Informática (INEGI), “Cuerpos de Agua." 2009, [Online]. Available: https://www.inegi.org.mx/app/biblioteca/ficha.html?upc=889463598435.

[104] L. Mayer et al., "The Nippon Foundation-GEBCO seabed 2030 project: The quest to see the world's oceans completely mapped by 2030," Geosci., 2018, doi: 10.3390/geosciences8020063.

[105] Instituto Nacional de Estadística Geografía e Informática (INEGI), “Conjunto de datos vectoriales Geológicos.” 2002, [Online]. Available: https://www.inegi.org.mx/temas/usosuelo/.

[106] IUCN and UNEP-WCMC, UNEP-WCMC and IUCN (year), Protected Planet: The World Database on Protected Areas (WDPA) [Online], [2019], Cambridge, UK: UNEP-WCMC and IUCN. Available at: www.protectedplanet.net. 2019.

[107] UNEP-WCMC, “UNEP-WCMC, WorldFish Centre, WRI, TNC (2018). Global distribution of warm-water coral reefs, compiled from multiple sources including the Millennium Coral Reef Mapping Project. Version 4.0. Includes contributions from IMaRSUSF and IRD (2005), IMaRS-USF (." UNEP-WCMC, WorldFish Centre, WRI, TNC (2018), 2018, [Online]. Available: https://data.unep-wcmc.org/datasets/1.

[108] S. E. Olajide, M. Lizam, and E. B. Olajide, “Understanding The Conceptual Definitions of Cost, Price, Worth and Value.," IOSR J. Humanit. Soc. Sci., vol. 21, no. 09, pp. 53-57, 2016, doi: 10.9790/0837-2109015357. 


\section{Appendix}

\section{A. Earthquakes and tsunamis as LEA constraints}

Several studies have investigated how wind turbines would behave in response to earthquakes. In 2003, Lavassas et al. [78] carried out an analysis and developed a design for a $1 \mathrm{MW}$, steel, $44 \mathrm{~m}$-high wind turbine tower that corresponded to the Greek AntiSeismic Code EAK 2000. It was concluded that seismic activity would only play a significant role in seismically-hazardous areas with a combination of medium and soft placement soil. Similarly, Ritschel et al. [79] performed two types of computational simulations: one, typically used for buildings and called "modal," as described by Clough et al. [80]; and one code specifically for wind turbines called "Flex5" [81]. The simulation was carried out to generate accelerograms in accordance with the European standard Eurocode 8 [82] for a Nordex N80 (onshore, $80 \mathrm{~m}$ rotor diameter, $60 \mathrm{~m}$ hub height, $2.5 \mathrm{MW}$ output) that was installed in a seismic region in Ryuy-Cho, Japan, a site with a peak ground acceleration of $0.3 \mathrm{~g}$. According to Ritschel et al., although both models returned slightly different results, with the Flex 5 one featuring more bending, simulated seismic shakes were negated by the designed turbine models. Moreover, according to a 2016 literature review on wind turbines and seismic hazards by Kastanos et al. [83], there exists a consensus in the engineering community that the loads caused by earthquakes of importance for wind turbines are horizontal and wind-driven, and that there is a "self-insolated effect" during the most destructive portion of an earthquake. Kastanos et al. supported their conclusions by drawing on observations of earthquakes in 1986 near an onshore wind farm in North Palm Springs, California, and in 2011 at the Kamisu offshore wind farm phase 1 in Tohoku, Japan.

Contrary to reports on hurricanes damaging wind turbines, the evidence of the effects of earthquakes can be exemplified clearly by the cases in Japan and California with offshore and onshore wind farms, respectively. In both instances, no turbine damage was reported. During the 2011 Great East Japan earthquake and tsunami (measuring 9.1 on the Richter Moment Magnitude Scale [84]), the Kamisu offshore wind farm contained seven Hitach HTW2.0-80 wind turbines of $2 \mathrm{MW}$ and with $60 \mathrm{~m}$ hub heights. Although the power was interrupted by grid checking after the tsunami, the wind farm continued providing power for three days following the tsunami, with no damage reported [85]. Matsunobu et al. [85] investigated the case and found that an "extreme wave + wind" is much more severe in terms of structural stress than a "Tsunami + power production" scenario, based on simulations of the Kamisu offshore phase 1 and the actual 2011 tsunami, which confirmed that the mono-pile wind turbine structures can withstand seismic vibrations. These results and observations were implemented in the design and construction of phase 2 of the same project. In this context, Bhattacharya et al. [86] noted that the use of offshore wind farms can even increase the seismic resilience of nuclear power plants, which are often close to the sea. They could also supplied the power for cooling systems, and would not fail for the same reasons as other emergency systems and, therefore, could help avoid a cascade of catastrophic consequences.

In the case of onshore wind, a study by Kübler et al. [87] from Swiss Re reports that in the Painted Hills onshore wind farm in California, none of the 65 wind turbines was destroyed by the earthquake in 2011. However, 48 of them had to undergo minor repairs. The wind farm is in the Riverside country, which is regarded as having a 75\% likelihood of an $\mathrm{M} 7.0^{\circ}$ earthquake occurring within the next 30 years. For more local cases, Oaxaca, Mexico is a site at which wind farms have operated since 1994 [88]. On the $7^{\text {th }}$ and $19^{\text {th }}$ of September 2017, two notable earthquakes occurred at this site; the first measured M8.2 and the second $\mathrm{M} 7.1^{\circ}$ [89]. In both instances, none of the 1,200 wind turbines were damaged [89]. Again, the power supply was also cut due to afflictions to the power lines, urban areas, and security grid issues [89].

Nevertheless, given the limited experience of only the last few decades and that not enough on-site experiments have been conducted, it cannot be concluded that wind turbines are earthquake-proof. This hazard analysis should be taken into consideration with 
the increased risk of a common failure of wind turbines [83]. In the case of solar technologies, during the 2011 earthquake and tsunami in Japan, existing solar panel operations were shut down due to grid problems rather than the destruction of the panels [90]. 
Table 4: Land constraints and buffer zones for the placement of VRES technologies in Mexico

\begin{tabular}{|c|c|c|c|c|c|c|c|}
\hline \multirow{2}{*}{ Group } & \multirow[b]{2}{*}{ No. } & Criterion & \multicolumn{3}{|c|}{ Exclusion zone $[<$ in meters] } & \multirow[b]{2}{*}{ References } & \multirow[b]{2}{*}{ Dataset source } \\
\hline & & Sub-criterion (optional) & Onshore wind & Open-field PV & Offshore wind & & \\
\hline \multirow{31}{*}{ 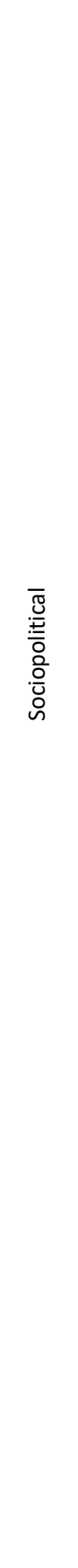 } & & Settlements & & & & & \\
\hline & 1 & Urban & 1200 & & & [34] & INEGI [91] \\
\hline & & Rural & 800 & 200 & 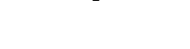 & & \\
\hline & 2 & Agricultural Areas & - & 0 & - & [34] & INEGI [92] \\
\hline & 3 & Airports & 4000 & 0 & - & [34] & Osm2sh [93] \\
\hline & & Roads & & & & & \\
\hline & 4 & Primary & 200 & & & [34] & INEGI [94] \\
\hline & & Secondary & 300 & 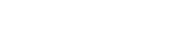 & 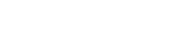 & & \\
\hline & 5 & Railways & 200 & - & - & [34] & Geofabrik [95] \\
\hline & 6 & Marine Shipping Routes & - & - & 3000 & [35] & ArcGIS [96] \\
\hline & 7 & Power or submarine lines & 200 & - & 500 & {$[34][35]$} & Geofabrik [95], NOAA [97] \\
\hline & 8 & Historical sites & 1000 & 1000 & - & [34] & INEL [98] \\
\hline & 9 & Archeological sites & 1000 & 1000 & - & [34] & INEL [98] \\
\hline & 10 & Recreational areas & 1000 & 1000 & - & [34] & MapCruzin [99] \\
\hline & 11 & Leisure and Camping & 1000 & 1000 & - & [34] & MapCruzin [99] \\
\hline & 12 & Tourism & 1000 & 1000 & - & [34] & MapCruzin [99] \\
\hline & & Industrial Areas & & & & & \\
\hline & 13 & Natural Gas facilities & 300 & 0 & & [34] & MapCruzin [99], SENER \\
\hline & & Oil facilities & 300 & & & & \\
\hline & 14 & Mining sites & 200 & 0 & - & [34] & SE [100] \\
\hline & 15 & Gas lines & 200 & - & - & [34] & SENER [101] \\
\hline & 16 & Power plants (>100MW) & 200 & - & - & [34] & IEA,SENER, INEGI [102] \\
\hline & 17 & Military areas & 1000 & 1000 & - & Added & Osm2sh [93] \\
\hline & 18 & Country borders & 500 & 500 & - & [42] & INEGI [91] \\
\hline & 19 & Harbors & 1000 & - & - & Added & SENER [101] \\
\hline & 20 & LNG terminals & 1000 & - & - & Added & SENER [101] \\
\hline & 21 & Total slope & $17^{\circ}$ & $10^{\circ}$ & & {$[201]$} & IISCS [61] \\
\hline & & Northward slope & - & $3^{\circ}$ & - & [34] & ] \\
\hline & & Water lines & & & & & \\
\hline & 22 & Rivers, Canals and Brooks & 200 & - & - & {$[34][35]$} & INEGI [103] \\
\hline & & Distance from coast & 1000 & 1000 & 15000 & & \\
\hline \multirow{7}{*}{$\begin{array}{l}\frac{\bar{v}}{\mathrm{n}} \\
\stackrel{\vec{c}}{a}\end{array}$} & & Water bodies & & & & & \\
\hline & 23 & Natural wells/Cenotes & 1000 & & & [34] & INEGI [103] \\
\hline & & Lakes and lagoons & 400 & 1000 & - & & \\
\hline & & Dams, Flooding zones & 200 & & & & \\
\hline & 24 & Woodlands & 300 & 0 & - & [34] & INEGI [92] \\
\hline & 25 & Jungles & 300 & 0 & - & Added & INEGI [92] \\
\hline & 26 & Wetlands & & & & [34] & INEGI [92] \\
\hline
\end{tabular}




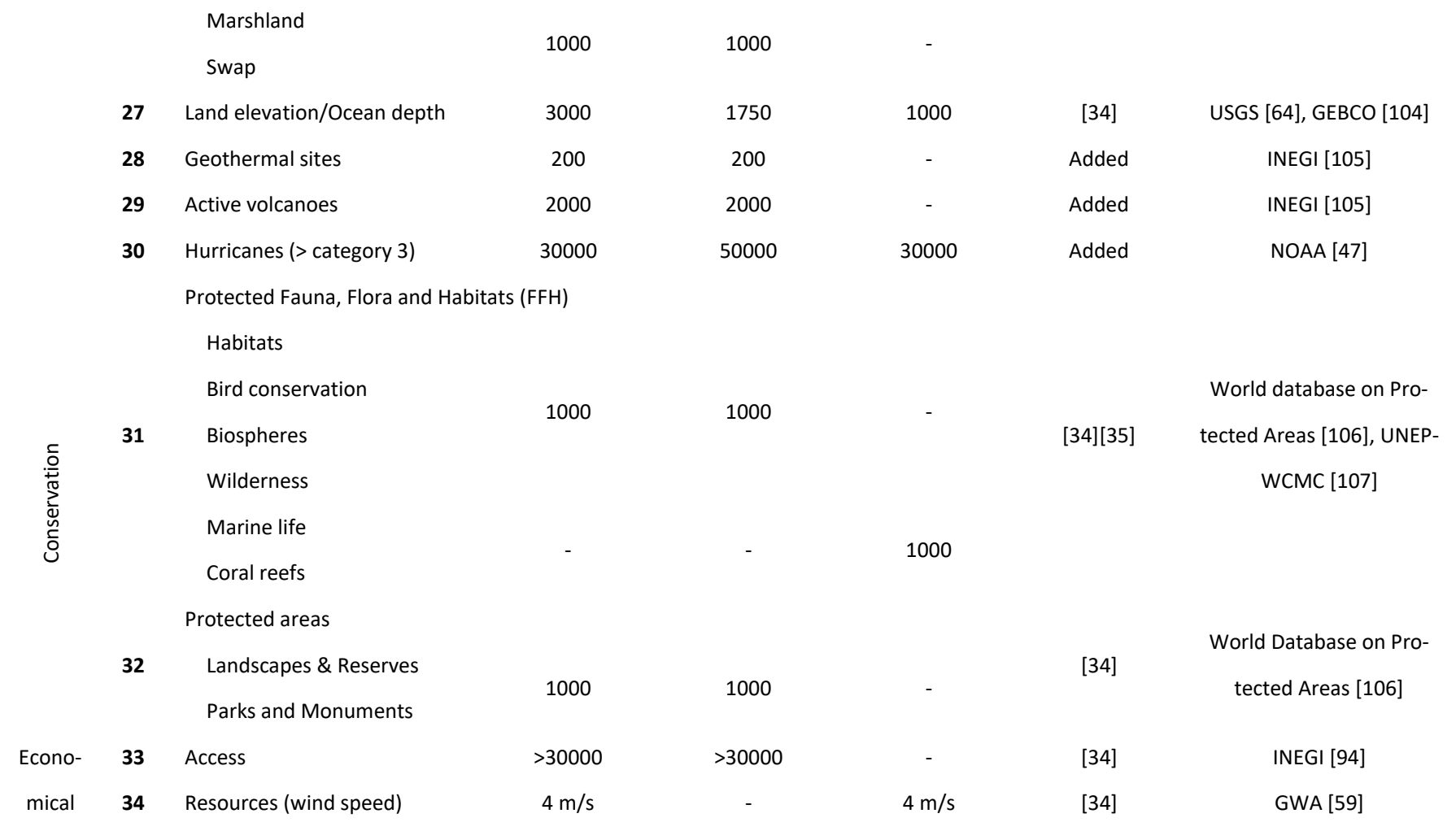

